Article

\title{
Synthesis and in Vitro Antiproliferative Evaluation of C-13 Epimers of Triazolyl-D-Secoestrone Alcohols: The First Potent 13 $\alpha$-D-Secoestrone Derivative
}

\author{
Johanna Szabó ${ }^{1}$, Nóra Jerkovics ${ }^{1}$, Gyula Schneider ${ }^{1}$, János Wölfling ${ }^{1}$, Noémi Bózsity ${ }^{2}$, \\ Renáta Minorics ${ }^{2}$, István Zupkó ${ }^{2}$ and Erzsébet Mernyák ${ }^{1, *}$ \\ 1 Department of Organic Chemistry, University of Szeged, Dóm tér 8, Szeged H-6720, Hungary; \\ johanna.szab@gmail.com (J.S.); jerkovicsnora@gmail.com (N.J.); schneider@chem.u-szeged.hu (G.S.); \\ wolfling@chem.u-szeged.hu (J.W.) \\ 2 Department of Pharmacodynamics and Biopharmacy, University of Szeged, Eötvös u. 6, Szeged H-6720, \\ Hungary; bozsity.noemi@pharm.u-szeged.hu (N.B.); minorics@pharm.u-szeged.hu (R.M.); \\ zupko@pharm.u-szeged.hu (I.Z.) \\ * Correspondence: bobe@chem.u-szeged.hu; Tel.: +36-62-544-277
}

Academic Editor: Maria Emília de Sousa

Received: 31 March 2016; Accepted: 29 April 2016; Published: 12 May 2016

\begin{abstract}
The syntheses of C-13 epimeric 3-[(1-benzyl-1,2,3-triazol-4-yl)methoxy]-D-secoestrones are reported. Triazoles were prepared from 3-(prop-2-inyloxy)-D-secoalcohols and $p$-substituted benzyl azides via $\mathrm{Cu}(\mathrm{I})$-catalyzed azide-alkyne cycloaddition (CuAAC). The antiproliferative activities of the products and their precursors were determined in vitro against a panel of human adherent cervical (HeLa, SiHa and C33A), breast (MCF-7, MDA-MB-231, MDA-MB-361 and T47D) and ovarian (A2780) cell lines by means of MTT assays. The orientation of the angular methyl group and the substitution pattern of the benzyl group of the azide greatly influenced the cell growth-inhibitory potential of the compounds. The $13 \beta$ derivatives generally proved to be more potent than their $13 \alpha$ counterparts. Introduction of a benzyltriazolylmethyl group onto the $3-\mathrm{OH}$ position seemed to be advantageous. One $13 \alpha$ compound containing an unsubstituted benzyltriazolyl function displayed outstanding antiproliferative activities against three cell lines.
\end{abstract}

Keywords: antiproliferative effect; azide-alkyne cycloaddition; D-secoestrone; triazole

\section{Introduction}

Anticancer drug design based on synthetic modifications of naturally occurring biomolecules may lead to nontoxic drug candidates with selective antitumoral potencies [1,2]. Estrone-based anticancer agents are already utilized in therapy, but one of the most important requirements of these drugs is a lack of original hormonal activity $[3,4]$. The literature provides evidence that inversion of the configuration at $\mathrm{C}-13$ or the opening of ring $\mathrm{D}$ of the estrane core may lead to the loss of estrogenic activity [5-9]. We recently reported that 3-benzyl ethers of D-secoestrone alcohol or oxime (compounds 1 and 2, Figure 1.) exert substantial in vitro cell growth-inhibitory action against a number of cancer cell lines, with $\mathrm{IC}_{50}$ values in the low micromolar or submicromolar range $[10,11]$. Compounds $\mathbf{1}$ and $\mathbf{2}$ were diversified at several sites in the molecule, including different modifications (etherifications, esterifications or debenzylations) at C-3 and / or C-17 and epimerization at C-13 (only in the case of 2). It was concluded that the nature of the 3- and 17-functional groups exerts a great impact on the antiproliferative behavior of the compounds. 3-Ethers proved to be more potent than their $3-\mathrm{OH}$ counterparts. Derivatives containing a 17-oxime function displayed more pronounced cytostatic properties than those of 17-hydroxymethyl derivatives. 3-Hydroxy-D-secooxime 2, but not the D-secoalcohol 1, was further derivatized by introducing a terminal alkyne function onto the 3-OH 
group by using propargyl bromide, and the resulting steroid alkyne was subjected to $\mathrm{Cu}(\mathrm{I})$-catalyzed azide-alkyne cycloaddition (CuAAC) with different substituted benzyl azides. The triazole moiety is frequently used as a linker in bioconjugates, because it is a good mimic of peptide bonding with high proteolytic and metabolic stability [12-14]. Introduction of a triazolyl function into the oxime 2 led to improved antiproliferative properties as compared with the 3-benzyl ether. The benzyltriazolylmethoxy D-secooxime 3 (Figure 1) exerted substantial cell growth-inhibitory effects against several human cancer cell lines.
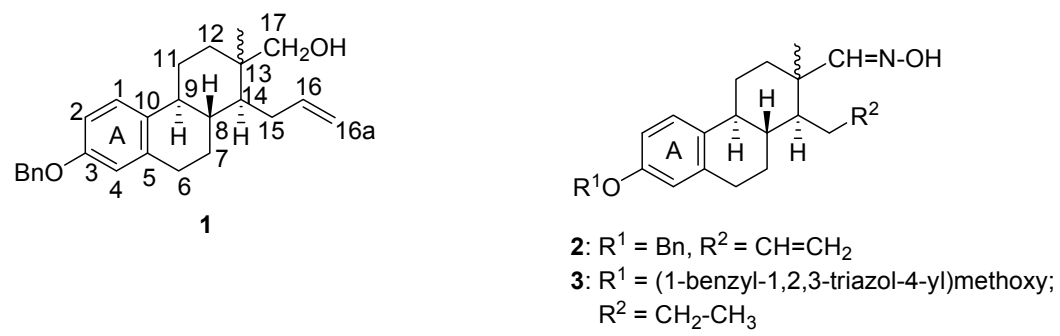

Figure 1. Structures of the potent antiproliferative D-secoestrones $\mathbf{1}$ and 2, 3 .

The abovementioned outstanding results suggested that it might be useful to introduce the benzyltriazolyl function onto other positions of the D-secoestrone scaffold. In a continuation of our earlier work, we focused herein on the synthesis of steroidal alkynes bearing a terminal alkyne function on the opened ring D. The D-secoestrone 17-carboxylic acids were reacted with propargylamine using peptide coupling reagents [15]. The reactions were carried out in both the $13 \alpha-$ and the $13 \beta$-estrone series in order to obtain more compounds for structure-activity determinations. The resulting $N$-propargyl 17-carboxamides were reacted with small molecule azides, such as substituted benzyl azides, and the resulting triazoles were evaluated for their antiproliferative activities against several human reproductive cancer cell lines. The activities of the compounds depended greatly on the substitution pattern of the aromatic ring of the benzyl azide moiety. 3-Benzyl ethers of $13 \beta$-( $p$-alkylbenzyl)triazoles displayed outstanding selective antiproliferative potential against A2780 cells.

There are already a number of literature examples of the synthesis of antiproliferative steroidal triazoles formed mainly from steroid azides and small molecule alkynes, such as phenylacetylenes. It has been found that the cytostatic activity of the resulting triazoles depends considerably on the substitution pattern of the phenyl group of the acetylene [16-22].

In view of the abovementioned recent results, we aimed to introduce the benzyltriazolylmethoxy moiety onto the 3-OH group of the C-13 epimeric D-secoalcohols. The synthesis of the D-secoestrone alkynes were first planned at position C-3, followed by the $\mathrm{CuAAC}$ reactions of the secosteroidal alkynes with substituted benzyl azides. The next goal was to perform comparative investigations of the in vitro antiproliferative activities of the products and their precursors by means of MTT assays against a panel of human adherent cervical (HeLa, SiHa and C33A), breast (MCF-7, MDA-MB-231, MDA-MB-361 and T47D) and ovarian (A2780) cell lines. Our main objective was to establish some structure-activity relationship, focusing particularly on the C-13 epimeric character of the compounds.

\section{Results}

We first synthesized steroidal alkynes in both the $13 \alpha$ - and the $13 \beta$-D-secoestrone series (Scheme 1). After removal of the benzyl protecting group of compounds $\mathbf{1}$ or $\mathbf{6}$ by hydrogenolysis, an excess of propargyl bromide was added in the presence of $\mathrm{K}_{2} \mathrm{CO}_{3}$, leading to the 3-(prop-2-inyloxy)-17-alcohols $\mathbf{9}$ or $\mathbf{1 0}$. The terminal alkynes 9 or $\mathbf{1 0}$ were reacted with benzyl azide (11a) or its substituted derivatives 11b-e under recently published CuAAC reaction conditions [20], furnishing the desired triazolyl compounds 12a-e or 13a-e in high yields. The structures of the triazoles were established from the corresponding ${ }^{1} \mathrm{H}$ - and ${ }^{13} \mathrm{C}-\mathrm{NMR}$ spectra. 


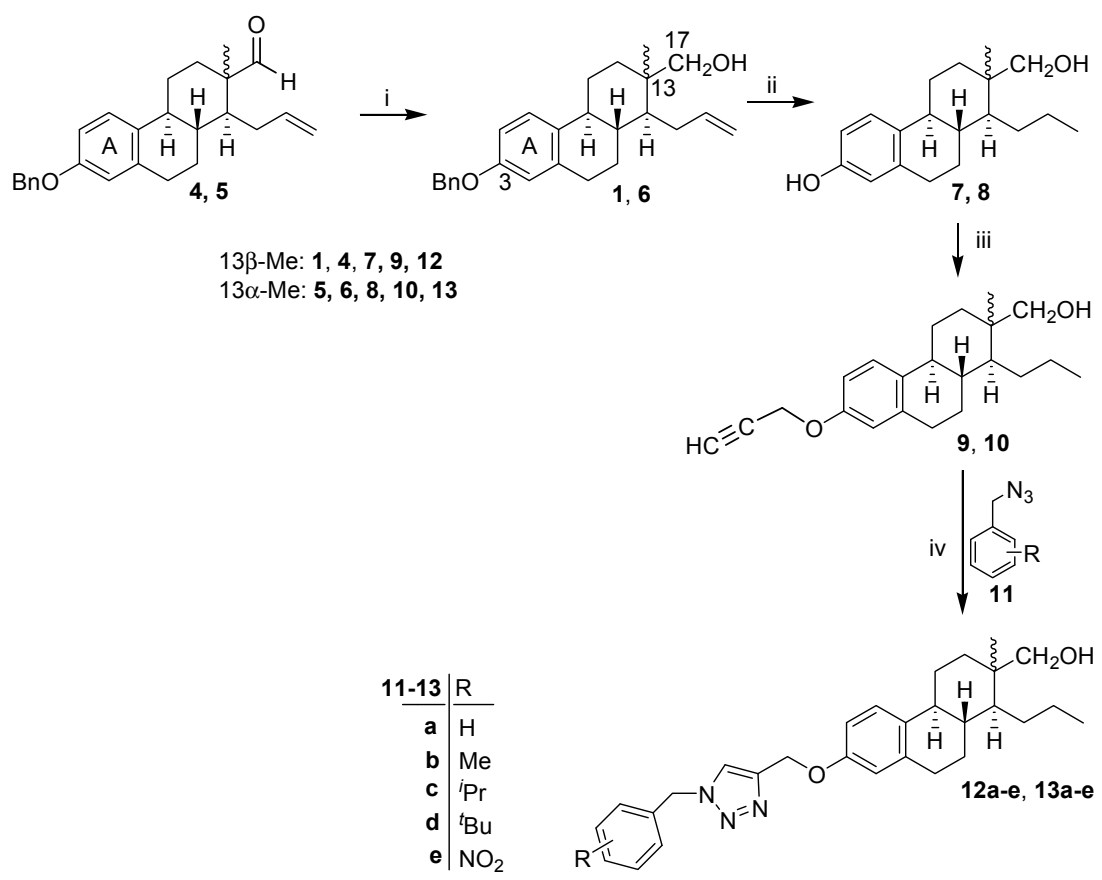

Scheme 1. Synthesis of D-secoestrone derivatives (12a-e and 13a-e). Reagents and conditions: (i) 5 equiv. $\mathrm{KBH}_{4}, \mathrm{CH}_{2} \mathrm{Cl}_{2}: \mathrm{MeOH}=1: 1,0{ }^{\circ} \mathrm{C}$-r.t., 0.5 h; (ii) $\mathrm{H}_{2}$ (20 bar), Pd/C, EtOAc, 3 h; (iii) propargyl bromide (1.5 equiv.), $\mathrm{K}_{2} \mathrm{CO}_{3}$ (7 equiv.), acetone, $70{ }^{\circ} \mathrm{C}, 24 \mathrm{~h}$; (iv) $\mathrm{CuI}$ (0.05 equiv.), $\mathrm{Ph}_{3} \mathrm{P}$ (0.1 equiv.), DIPEA (3 equiv.), toluene, reflux, $2 \mathrm{~h}$.

The cell growth-inhibitory activities of the triazoles and their precursors were determined in vitro against a panel of human adherent cervical (HeLa, SiHa and C33A), breast (MCF-7, MDA-MB-231, MDA-MB-361 and T47D) and ovarian (A2780) cell lines by means of MTT assays (Table 1). The 3-benzyl ether of the 13 $\beta$-D-secoalcohol 1 selectively inhibited the growth of MCF-7 cells, with inhibition values $>80 \%$ at $10 \mu \mathrm{M}$. Its C-13 epimer 6 at $10 \mu \mathrm{M}$ displayed $<50 \%$ inhibition on all the examined cell lines. The 3-OH derivatives 7 and $\mathbf{8}$ exerted low antiproliferative potentials at both concentrations (even at $30 \mu \mathrm{M}$ ). Among the propargyl derivatives 9 and 10, only the $13 \beta$ epimer 9 inhibited the growth of nearly all the cell lines by $>50 \%$ at $30 \mu \mathrm{M}$. As concerns the triazoles, 12a displayed the highest antiproliferative activity against A2780, HeLa and C33A, with inhibition values $>80 \%$ at $10 \mu \mathrm{M}$. The $p$-methyl derivative $\mathbf{1 2} \mathbf{b}$ displayed somewhat lower potential against the abovementioned cell lines. Compounds 12c and 12d inhibited the growth of only two cell lines (A2780 and C33A) by $>80 \%$ at $30 \mu \mathrm{M}$. The $13 \alpha$-epimeric triazole 13a displayed substantial antiproliferative potential against A2780, Hela and C33A. 13b inhibited the growth of nearly all cell lines by $>50 \%$ at $30 \mu \mathrm{M}$. The other $13 \alpha$-epimeric triazoles $13 \mathbf{c}-\mathbf{e}$ did not influence the growth of the cell lines effectively.

Compound 12a displayed limited growth inhibition against noncancerous human fibroblast cell line (MRC-5) with values $<30 \%$ even at $30 \mu \mathrm{M}$.

\section{Discussion}

The benzyl protecting groups of the D-secoalcohols 1, 6 in both the $13 \alpha$-and the $13 \beta$-D-secoestrone series were removed by hydrogenolysis, using $\mathrm{Pd} / \mathrm{C}$ as a catalyst. The saturation of the $\delta$-alkenyl side-chain occurred simultaneously. The resulting 3,17-diols 7 and 8 were selectively alkylated at their 3-OH functions, taking advantage of the more acidic behavior of the phenolic over the alcoholic $\mathrm{OH}$ groups. The propargylations led to the desired terminal alkynes $\mathbf{9}$ or $\mathbf{1 0}$ in high yields. The steroidal alkynes were subjected to azide-alkyne cycloadditions under the earlier published reaction conditions [20], using a catalytic amount of $\mathrm{CuI}$ and $\mathrm{PPh}_{3}$ as an accelerating ligand. 
Table 1. Antiproliferative properties of the synthesized compounds. Mean value from two independent determinations with five parallel wells; standard deviation $<15 \%$.

\begin{tabular}{|c|c|c|c|c|c|c|c|c|c|}
\hline \multirow{2}{*}{ Comp. } & \multirow{2}{*}{ Conc. $(\mu \mathbf{M})$} & \multicolumn{8}{|c|}{ Inhibition $(\%) \pm$ SEM (Calculated $\left.\mathrm{IC}_{50}\right)^{1}$} \\
\hline & & A2780 & Hela & SiHa & C33A & MCF-7 & T47D & MDA-MB-231 & MDA-MB-361 \\
\hline \multirow[b]{2}{*}{1} & 10 & $42.3 \pm 0.9$ & $31.4 \pm 1.6$ & -2 & $39.2 \pm 0.6$ & $81.3 \pm 0.7$ & $26.1 \pm 2.0$ & - & $28.2 \pm 0.4$ \\
\hline & 30 & $97.5 \pm 0.1$ & $97.9 \pm 0.3$ & $84.3 \pm 0.9$ & $86.9 \pm 0.7$ & $\begin{array}{c}97.4 \pm 0.3 \\
\quad(6.4)\end{array}$ & $87.2 \pm 0.9$ & $84.5 \pm 0.9$ & $87.6 \pm 0.4$ \\
\hline \multirow{2}{*}{6} & 10 & $43.6 \pm 2.4$ & $20.1 \pm 1.8$ & - & $40.4 \pm 2.1$ & - & - & - & - \\
\hline & 30 & $55.4 \pm 2.5$ & $60.3 \pm 1.4$ & $49.7 \pm 1.4$ & $53.8 \pm 1.1$ & $36.4 \pm 1.2$ & $59.6 \pm 0.8$ & $49.3 \pm 1.6$ & $77.2 \pm 1.3$ \\
\hline \multirow{2}{*}{7} & 10 & - & - & - & $40.5 \pm 0.8$ & $24.3 \pm 2.6$ & - & - & - \\
\hline & 30 & $35.1 \pm 0.8$ & $40.7 \pm 1.7$ & - & $42.3 \pm 1.8$ & $51.6 \pm 2.9$ & - & - & - \\
\hline \multirow{2}{*}{8} & 10 & - & $23.7 \pm 0.9$ & - & - & - & - & - & - \\
\hline & 30 & - & $64.5 \pm 1.1$ & - & - & - & $23.0 \pm 1.7$ & - & - \\
\hline \multirow{2}{*}{9} & 10 & $22.4 \pm 1.0$ & $21.5 \pm 0.8$ & - & $30.0 \pm 1.1$ & - & - & $36.8 \pm 2.7$ & - \\
\hline & 30 & $70.7 \pm 0.4$ & $89.3 \pm 1.9$ & $84.5 \pm 0.5$ & $70.1 \pm 0.7$ & $52.5 \pm 1.0$ & $37.7 \pm 1.3$ & $81.0 \pm 1.1$ & $59.0 \pm 2.9$ \\
\hline \multirow{2}{*}{10} & 10 & - & - & - & - & - & - & - & - \\
\hline & 30 & $29.7 \pm 1.9$ & $36.9 \pm 1.8$ & - & $39.9 \pm 1.1$ & $23.3 \pm 0.6$ & $45.5 \pm 0.6$ & $28.2 \pm 2.2$ & - \\
\hline \multirow[b]{2}{*}{$12 a$} & 10 & $81.5 \pm 1.1$ & $85.4 \pm 0.3$ & $21.2 \pm 1.1$ & $90.0 \pm 0.3$ & $66.3 \pm 0.3$ & $51.0 \pm 1.1$ & $53.5 \pm 1.2$ & $59.3 \pm 1.4$ \\
\hline & 30 & $\begin{array}{c}88.0 \pm 0.1 \\
(0.9)\end{array}$ & $\begin{array}{c}91.7 \pm 0.3 \\
(1.1)[23]\end{array}$ & $34.5 \pm 1.2$ & $\begin{array}{c}95.1 \pm 0.2 \\
(1.8)[23]\end{array}$ & $\begin{array}{c}74.5 \pm 1.7 \\
(1.5)\end{array}$ & $54.4 \pm 1.8$ & $59.6 \pm 1.8$ & $45.2 \pm 1.1$ \\
\hline \multirow[b]{2}{*}{$12 b$} & 10 & $96.8 \pm 0.2$ & $52.6 \pm 0.9$ & $48.1 \pm 0.8$ & $86.8 \pm 0.8$ & $71.6 \pm 1.0$ & $65.7 \pm 1.4$ & $58.3 \pm 0.7$ & $87.2 \pm 0.5$ \\
\hline & 30 & $\begin{array}{c}97.4 \pm 0.1 \\
\quad(3.8)\end{array}$ & $65.4 \pm 0.9$ & $64.3 \pm 1.0$ & $\begin{array}{c}93.9 \pm 0.9 \\
(5.0)\end{array}$ & $\begin{array}{c}73.9 \pm 1.0 \\
(5.0)\end{array}$ & $66.4 \pm 1.2$ & $\begin{array}{c}86.1 \pm 0.3 \\
(8.3)\end{array}$ & $\begin{array}{c}89.3 \pm 1.1 \\
(4.4)\end{array}$ \\
\hline \multirow[b]{2}{*}{$12 c$} & 10 & $83.3 \pm 0.5$ & $27.1 \pm 1.7$ & - & $57.5 \pm 1.8$ & - & - & $33.6 \pm 0.8$ & $47.1 \pm 2.9$ \\
\hline & 30 & $\begin{array}{c}93.4 \pm 0.1 \\
(5.4)\end{array}$ & $66.0 \pm 2.4$ & $35.6 \pm 0.3$ & $\begin{array}{c}84.6 \pm 0.9 \\
(8.3)\end{array}$ & $66.1 \pm 1.7$ & $53.0 \pm 1.6$ & $48.9 \pm 0.7$ & $45.6 \pm 0.6$ \\
\hline \multirow{2}{*}{$12 d$} & 10 & $20.5 \pm 1.2$ & $30.9 \pm 3.0$ & - & $25.3 \pm 1.5$ & - & - & - & - \\
\hline & 30 & $29.0 \pm 2.0$ & $45.9 \pm 1.1$ & - & $64.0 \pm 1.8$ & $29.5 \pm 2.7$ & $28.9 \pm 0.9$ & - & $45.5 \pm 1.2$ \\
\hline \multirow[b]{2}{*}{$12 e$} & 10 & $86.4 \pm 0.3$ & $46.3 \pm 2.5$ & $25.5 \pm 2.0$ & $81.4 \pm 1.9$ & $61.1 \pm 1.6$ & $41.5 \pm 2.0$ & $49.8 \pm 0.7$ & $47.5 \pm 0.7$ \\
\hline & 30 & $\begin{array}{c}89.6 \pm 0.3 \\
(4.6)\end{array}$ & $72.5 \pm 1.1$ & $23.2 \pm 1.2$ & $\begin{array}{c}88.9 \pm 0.6 \\
(5.4)\end{array}$ & $\begin{array}{c}63.4 \pm 0.9 \\
(6.6)\end{array}$ & $49.7 \pm 2.5$ & $48.8 \pm 0.9$ & $46.7 \pm 1.0$ \\
\hline
\end{tabular}


Table 1. Cont.

\begin{tabular}{|c|c|c|c|c|c|c|c|c|c|}
\hline \multirow{2}{*}{ Comp. } & \multirow{2}{*}{ Conc. $(\mu \mathrm{M})$} & \multicolumn{8}{|c|}{ Inhibition $(\%) \pm$ SEM $\left(\text { Calculated } \mathrm{IC}_{50}\right)^{1}$} \\
\hline & & A2780 & Hela & SiHa & C33A & MCF-7 & T47D & MDA-MB-231 & MDA-MB-361 \\
\hline \multirow[b]{2}{*}{$13 a$} & 10 & $73.4 \pm 0.9$ & $70.0 \pm 0.7$ & $41.8 \pm 1.7$ & $80.0 \pm 0.5$ & $39.4 \pm 1.2$ & $36.6 \pm 0.7$ & $38.2 \pm 2.2$ & $65.8 \pm 1.0$ \\
\hline & 30 & $\begin{array}{c}83.8 \pm 0.8 \\
(3.0)\end{array}$ & $\begin{array}{c}90.9 \pm 0.3 \\
(5.3)\end{array}$ & $37.1 \pm 1.0$ & $\begin{array}{c}93.9 \pm 0.1 \\
(4.4)\end{array}$ & $73.8 \pm 1.1$ & $69.1 \pm 0.6$ & $59.7 \pm 1.6$ & $48.6 \pm 1.4$ \\
\hline \multirow[b]{2}{*}{$13 b$} & 10 & $54.3 \pm 0.8$ & $33.9 \pm 1.1$ & - & $26.6 \pm 1.8$ & - & $43.2 \pm 0.3$ & $36.7 \pm 1.8$ & - \\
\hline & 30 & $\begin{array}{c}81.0 \pm 0.1 \\
\quad(9.8)\end{array}$ & $74.4 \pm 0.9$ & $49.4 \pm 0.8$ & $86.1 \pm 0.6$ & $65.6 \pm 1.9$ & $89.3 \pm 0.8$ & $56.8 \pm 1.2$ & $48.7 \pm 1.0$ \\
\hline \multirow{2}{*}{$13 c$} & 10 & - & $21.3 \pm 2.3$ & - & - & - & - & - & - \\
\hline & 30 & $52.7 \pm 1.9$ & $40.6 \pm 0.9$ & - & $41.7 \pm 1.2$ & $20.1 \pm 0.8$ & $39.4 \pm 1.7$ & $28.1 \pm 0.7$ & $25.7 \pm 2.8$ \\
\hline \multirow{2}{*}{$13 d$} & 10 & $20.0 \pm 1.9$ & $24.4 \pm 1.3$ & - & $26.1 \pm 0.9$ & - & - & - & - \\
\hline & 30 & $44.8 \pm 1.1$ & $36.9 \pm 0.8$ & $23.0 \pm 1.2$ & $66.3 \pm 0.6$ & $30.8 \pm 1.7$ & $44.4 \pm 1.7$ & $37.5 \pm 1.6$ & $40.3 \pm 2.1$ \\
\hline \multirow{2}{*}{$13 e$} & 10 & - & - & - & - & - & - & - & - \\
\hline & 30 & $29.1 \pm 2.3$ & $48.3 \pm 2.0$ & - & $34.2 \pm 1.3$ & - & $22.8 \pm 1.9$ & - & - \\
\hline \multirow[b]{2}{*}{ Cisplatin } & 10 & $83.6 \pm 1.2$ & $42.6 \pm 2.3$ & $88.6 \pm 0.5$ & $83.8 \pm 0.8$ & $66.9 \pm 1.8$ & $51.0 \pm 2.0$ & - & $67.5 \pm 1.0$ \\
\hline & 30 & $95.0 \pm 0.3$ & $99.9 \pm 0.3$ & $90.2 \pm 1.8$ & $94.0 \pm 0.6$ & $96.8 \pm 0.4$ & $57.9 \pm 1.5$ & $71.5 \pm 1.2$ & $87.8 \pm 1.1$ \\
\hline
\end{tabular}

': Mean value from two independent determinations with five parallel wells; standard deviation $<15 \%{ }^{2}$ : Inhibition values $<20 \%$ are not presented. 
All the CuAACs furnished the triazoles 12a-e or 13a-e in excellent yields. The orientation of the angular methyl group and the substitution pattern of the $N$-benzyl ring did not influence the yields of the reactions, as it was expected.

From the comparison of the ${ }^{1} \mathrm{H}-\mathrm{NMR}$ spectra of the 3-benzyl ethers $\mathbf{1}$ and $\mathbf{6}$ with those of their phenolic counterparts 7 and $\mathbf{8}$, the absence of the proton signals of the benzylic protecting group from the aromatic region, and the presence of the singlet at around $9 \mathrm{ppm}$ clearly indicates the successful removal of the protecting group. In the ${ }^{1} \mathrm{H}-\mathrm{NMR}$ spectra of $\mathbf{9}$ and $\mathbf{1 0}$, the introduction of the propargyl group onto the $3-\mathrm{O}$ is supported by the singlet at $2.5 \mathrm{ppm}$, which relates to the terminal alkyne function, and by the singlet of double intensity (the $\mathrm{OCH}_{2}$ group of the ether function). In the ${ }^{13} \mathrm{C}-\mathrm{NMR}$ spectra of the triazoles 12a-e and $\mathbf{1 3} \mathbf{a}-\mathbf{e}$, the two $\mathrm{OCH}_{2}$ and the $\mathrm{NCH}_{2}$ carbon signals appear in the 55-70 ppm range, indicating the presence of the $\mathrm{N}$-benzyltriazolylmethoxy moiety on $\mathrm{C}-3$. There are additional quaternary carbon signals in the aromatic region of the spectra of the triazoles, belonging to the newly introduced moiety. As concerns the epimeric character of the triazoles, C-18 in the $13 \beta$ epimers 12a-e appears at higher chemical shift ( $25 \mathrm{ppm})$ than that in the $13 \alpha$ counterparts $13 \mathbf{a}-\mathbf{e}(\sim 16 \mathrm{ppm})$.

The results of the MTT assays of the 3-OH 7 and 8 or 3-ether compounds 1, 6, 9 and 10 revealed their substantially lower inhibitory properties than those of some triazoles (Table 1). 3-OH derivatives 7, 8 exerted the lowest growth inhibition, thus the presence of the phenolic $\mathrm{OH}$ function in the D-secoestrone seems to be disadvantageous. A bulky apolar benzyl or a smaller propargyl ether protecting group on C-3 improved the antiproliferative behavior, leading to values $>80 \%$ or $>50 \%$ being attained at $30 \mu \mathrm{M}$. Introduction of a triazolylmethyl linker between the oxygen on C-3 and the benzyl protecting group seemed to be beneficial in both C-13 epimer series. As concerns the triazoles 12a-e and 13a-e, the $13 \beta$ epimers 12a-e displayed overall higher inhibitions than their $13 \alpha$ counterparts 13a-e. In both series, the most potent derivative 12a or 13a was that bearing an unsubstituted $N$-benzyl group, as observed earlier in the case of the D-secooxime 3 [11]. The characterization of the mechanism of the antiproliferative action of 12a on the three cervical cancer cell lines in under publication [23]. However, 12a displayed unusual behavior against the panel of breast cancer cell lines, with inhibition levels $<75 \%$ even at $30 \mu \mathrm{M}$. It can be stated that the presence of an electron-donating $p$-alkyl or an electron-withdrawing $p$-nitro substituent on the $N$-benzyl ring of the triazoles $12 c-\mathbf{e}$ and $13 c-\mathbf{e}$ usually proved to be detrimental for biological activity. The inhibitory effects decreased as the size of the $p$-alkyl moiety increased. It may be noted that to date there have been no reports of the $13 \alpha$-D-secoestrone derivatives with high antitumor activity.

The majority of cervical carcinomas originate from high-risk human papillomavirus (HPV) infections of the epithelial layer of the cervix, including HPV-16, -18, -31 and -35 among others [24]. HeLa is known to be an HPV-18-positive cell line [25]. SiHa and C33A differ in HPV-16 status, since only $\mathrm{SiHa}$ is infected by it. This pathological difference may cause a difference in antiproliferative action of the compounds against these cell lines. Our test compounds did not significantly influence the proliferation of SiHa cells, except in the cases of two ethers of the $13 \beta$ epimer $\mathbf{1}$ or $\mathbf{9}$, with values of $>80 \%$ at $30 \mu \mathrm{M}$. However, several triazoles were similarly potent against HeLa or C33A, independently of the HPV status of the cell lines.

Substantial differences in the growth-inhibitory potential of compound $\mathbf{1}$ were determined against a panel of breast cancer cell lines differing in receptor status [26]. These cell lines included T47D (expressing the estrogen, progesterone and androgen receptors), MDA-MB-361 (expressing the estrogen receptor and HER2) and a triple-negative cell line, MDA-MB-231. Compound 1 proved to be selective against cell line MCF-7. Since the other test compounds displayed similar activities against this cell line panel, the receptor status of the cells seems irrelevant, as we earlier observed for certain recently published D-homoestrones [27].

The cancer selectivity of one of the most promising compounds 12a was tested by means of the same MTT assay, using non-cancerous human fibroblast cells MRC5. Compound 12a elicited growth inhibition of $24.9 \% \pm 4.9 \%$ (mean \pm SEM) when applied at a final concentration of $30 \mu \mathrm{M}$. The reference agent cisplatin at the same concentration caused a more substantial inhibition $(70.7 \% \pm 1.3 \%)$. 
On the basis of these results, it could be concluded that the selected compound displays limited growth-inhibitory action against these non-cancerous cells, indicating some selective toxicity towards fast growing cancer cells.

\section{Materials and Methods}

\subsection{General Information}

Melting points ( $\mathrm{mp}$ ) were determined with a Kofler hot-stage apparatus and are uncorrected. Elemental analyses were performed with a CHN analyzer model 2400 (Perkin-Elmer, Waltham, MA, USA). Thin-layer chromatography: silica gel $60 \mathrm{~F}_{254}$; layer thickness $0.2 \mathrm{~mm}$ (Merck, New York, NY, USA); eluents: (A) 2\% ethyl acetate/98\% dichloromethane, (B) 10\% ethyl acetate/90\% dichloromethane; detection with iodine or UV (365 nm) after spraying with 5\% phosphomolybdic acid in $50 \%$ aqueous phosphoric acid and heating at $100-120^{\circ} \mathrm{C}$ for $10 \mathrm{~min}$. Flash chromatography: silica gel $60,40-63 \mu \mathrm{m}$ (Merck). ${ }^{1} \mathrm{H}-\mathrm{NMR}$ spectra were recorded in $\mathrm{CDCl}_{3}$ solution (if not otherwise stated) with a DRX-500 instrument (Bruker, Billerica, MA, USA) at $500 \mathrm{MHz}$, with $\mathrm{Me}_{4} \mathrm{Si}$ as internal standard. ${ }^{13} \mathrm{C}-\mathrm{NMR}$ spectra were recorded with the same instrument at $125 \mathrm{MHz}$ under the same conditions.

\subsection{Chemistry}

\subsubsection{General Procedure for the Synthesis of 3-Benzyloxy-D-secoalcohols 1, 6}

D-secoaldehyde 4 or 5 [10] (374 mg, $1.00 \mathrm{mmol}$ ) was dissolved in a 1:1 mixture of dichloromethane and methanol $(10 \mathrm{~mL})$ in an ice-water bath and potassium borohydride $(270 \mathrm{mg}, 5.00 \mathrm{mmol})$ was added in small portions. The mixture was allowed to stand at room temperature for $0.5 \mathrm{~h}$, then diluted with water and extracted with dichloromethane. The combined organic phases were washed with water until neutral and dried over sodium sulfate. The crude product was subjected to flash chromatography with dichloromethane as eluent.

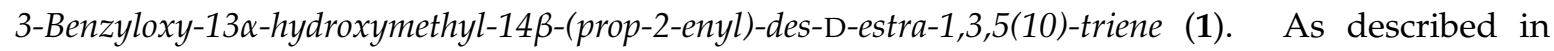
Section 4.2 .1 , D-secoaldehyde $4(374 \mathrm{mg}, 1.00 \mathrm{mmol})$ was reacted with potassium borohydride ( $270 \mathrm{mg}, 5.00 \mathrm{mmol})$. Compound 1 is identical with the compound described in the literature [10]: oil, $\mathrm{R}_{\mathrm{f}}=0.53(\mathrm{~A}) .{ }^{1} \mathrm{H}-\mathrm{NMR} \delta \mathrm{ppm} 0.80\left(\mathrm{~s}, 3 \mathrm{H}, 18-\mathrm{H}_{3}\right), 2.85\left(\mathrm{~m}, 2 \mathrm{H}, 6-\mathrm{H}_{2}\right), 3.30$ and $3.61(2 \times \mathrm{m}, 2 \times 1 \mathrm{H}$, $\left.17-\mathrm{H}_{2}\right), 5.03\left(\mathrm{~m}, 2 \mathrm{H}, 16 \mathrm{a}-\mathrm{H}_{2}\right), 5.04\left(\mathrm{~s}, 2 \mathrm{H}, \mathrm{OCH}_{2}\right), 5.93(\mathrm{~m}, 1 \mathrm{H}, 16-\mathrm{H}), 6.73(\mathrm{~d}, 1 \mathrm{H}, J=2.3 \mathrm{~Hz}, 4-\mathrm{H}), 6.79$ $(\mathrm{dd}, 1 \mathrm{H}, J=8.5 \mathrm{~Hz}, J=2.3 \mathrm{~Hz}, 2-\mathrm{H}), 7.22(\mathrm{~d}, 1 \mathrm{H}, J=8.5 \mathrm{~Hz}, 1-\mathrm{H}), 7.32\left(\mathrm{t}, 1 \mathrm{H}, J=7.3 \mathrm{~Hz}, 4^{\prime}-\mathrm{H}\right), 7.38(\mathrm{t}$, $2 \mathrm{H}, J=7.3 \mathrm{~Hz}, 3^{\prime}-\mathrm{H}$ and $\left.5^{\prime}-\mathrm{H}\right), 7.43\left(\mathrm{~d}, 2 \mathrm{H}, J=7.3 \mathrm{~Hz}, 2^{\prime}-\mathrm{H}\right.$ and $\left.6^{\prime}-\mathrm{H}\right)$.

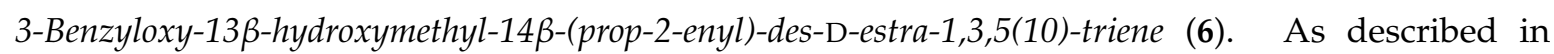
Section 4.2.1, D-secoaldehyde $5(374 \mathrm{mg}, 1.00 \mathrm{mmol})$ was reacted with potassium borohydride $(270 \mathrm{mg}$, $5.00 \mathrm{mmol})$. Compound 6 was obtained as a white solid. Yield: $347 \mathrm{mg}(92 \%) . \mathrm{Mp} \mathrm{50-52}{ }^{\circ} \mathrm{C}$, $\mathrm{R}_{\mathrm{f}}=0.47$ (A). Anal. Calcd. for $\mathrm{C}_{26} \mathrm{H}_{32} \mathrm{O}_{2}: \mathrm{C}, 82.94 ; \mathrm{H}, 8.57$. Found: C, 83.05; H, 8.66. ${ }^{1} \mathrm{H}-\mathrm{NMR}$ $\delta$ ppm $1.06\left(\mathrm{~s}, 3 \mathrm{H}, 18-\mathrm{H}_{3}\right) ; 2.82\left(\mathrm{~m}, 2 \mathrm{H}, 6-\mathrm{H}_{2}\right) ; 3.53$ and $3.72\left(2 \times \mathrm{d}, 2 \times 1 \mathrm{H}, J=10.8 \mathrm{~Hz}, 17-\mathrm{H}_{2}\right) ; 4.96-5.07$ (overlapping multiplets, $\left.4 \mathrm{H}, 16 \mathrm{a}-\mathrm{H}_{2}, \mathrm{OCH}_{2}\right) ; 5.87(\mathrm{~m}, 1 \mathrm{H}, 16-\mathrm{H}) ; 6.71(\mathrm{~s}, 1 \mathrm{H}, 4-\mathrm{H}) ; 6.79(\mathrm{~d}, 1 \mathrm{H}, J=8.3 \mathrm{~Hz}$, 2-H); $7.21(\mathrm{~d}, 1 \mathrm{H}, J=8.3 \mathrm{~Hz}, 1-\mathrm{H}) ; 7.32\left(\mathrm{t}, 1 \mathrm{H}, J=6.9 \mathrm{~Hz}, 4^{\prime}-\mathrm{H}\right) ; 7.38\left(\mathrm{t}, 2 \mathrm{H}, J=7.1 \mathrm{~Hz}, 3^{\prime}-\mathrm{H}\right.$ and $\left.5^{\prime}-\mathrm{H}\right)$; $7.42\left(\mathrm{~d}, 2 \mathrm{H}, \mathrm{J}=6.7 \mathrm{~Hz}, 2^{\prime}-\mathrm{H}\right.$ and $\left.6^{\prime}-\mathrm{H}\right),{ }^{13} \mathrm{C}-\mathrm{NMR} \delta$ ppm $25.3(\mathrm{C}-18) ; 26.5 ; 27.8 ; 30.3 ; 32.4 ; 35.6 ; 38.8 ; 41.2 ;$ 43.7; 50.7; 64.5 (C-17); $69.9\left(\mathrm{OCH}_{2}\right) ; 112.4(\mathrm{C}-2) ; 114.5(\mathrm{C}-4) ; 114.6(\mathrm{C}-16 \mathrm{a}) ; 126.3(\mathrm{C}-1) ; 127.4\left(2 \mathrm{C}: \mathrm{C}-3^{\prime}, 5^{\prime}\right)$; 127.8; 128.5 (2C:C-2' ,6'); $133.0\left(\mathrm{C}-4^{\prime}\right) ; 137.3$ (C-10); 137.9 (C-5); 140.2 (C-16); 156.8 (C-3).

\subsubsection{General Procedure for the Synthesis of 3-Hydroxy-D-secoestrones 7, 8}

A suspension of 1 or $6(376 \mathrm{mg}, 1.00 \mathrm{mmol})$ and Pd/C (0.30 g, 10\%) in ethyl acetate $(20 \mathrm{~mL})$ was subjected to 20 bar of hydrogen pressure at room temperature for $3 \mathrm{~h}$. The catalyst was then removed by filtration through a short pad of silica gel. After evaporation of the solvent in vacuo, the crude product was subjected to flash chromatography with dichloromethane as eluent. 


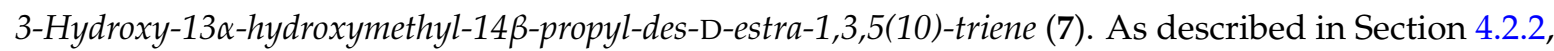
compound 1 (376 mg, $1.00 \mathrm{mmol})$ was subjected to hydrogenolysis. Compound 7 is identical with compound described in the literature [10]: $\mathrm{Mp} 60-62{ }^{\circ} \mathrm{C}, \mathrm{R}_{\mathrm{f}}=0.17(\mathrm{~A}) .{ }^{1} \mathrm{H}-\mathrm{NMR} \delta \mathrm{ppm} 0.77(\mathrm{~s}, 3 \mathrm{H}$, $\left.18-\mathrm{H}_{3}\right), 2.82\left(\mathrm{~m}, 2 \mathrm{H}, 6-\mathrm{H}_{2}\right), 3.35$ and $3.52\left(2 \times \mathrm{d}, 2 \times 1 \mathrm{H}, \mathrm{J}=10.9 \mathrm{~Hz}, 17-\mathrm{H}_{2}\right), 6.56(\mathrm{~d}, 1 \mathrm{H}, \mathrm{J}=2.3 \mathrm{~Hz}, 4-\mathrm{H})$, $6.63(\mathrm{dd}, 1 \mathrm{H}, J=8.5 \mathrm{~Hz}, J=2.3 \mathrm{~Hz}, 2-\mathrm{H}), 7.16(\mathrm{~d}, 1 \mathrm{H}, J=8.5 \mathrm{~Hz}, 1-\mathrm{H})$.

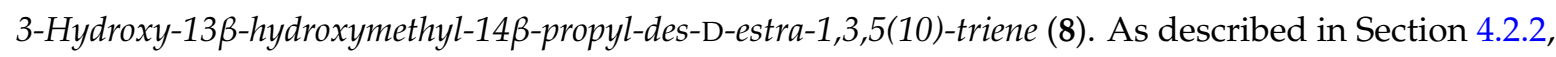
compound 6 (376 mg, $1.00 \mathrm{mmol}$ ) was subjected to hydrogenolysis. The chromatographic purification of the crude product yielded 8 as a white solid (268 mg, 93\%). Mp 50-52 ${ }^{\circ} \mathrm{C}, \mathrm{R}_{\mathrm{f}}=0.27$ (A). Anal. Calcd. for $\mathrm{C}_{19} \mathrm{H}_{28} \mathrm{O}_{2}$ : C, 79.12; H, 9.78. Found: $C, 79.25 ; \mathrm{H}, 9.96$. DMSO- $d_{6}{ }^{1} \mathrm{H}-\mathrm{NMR} \delta \mathrm{ppm} 0.89(\mathrm{t}, 3 \mathrm{H}$, $\left.J=6.7 \mathrm{~Hz}, 16 \mathrm{a}-\mathrm{H}_{3}\right) ; 1.17\left(\mathrm{~s}, 3 \mathrm{H}, 18-\mathrm{H}_{3}\right) ; 2.69\left(\mathrm{~m}, 2 \mathrm{H}, 6-\mathrm{H}_{2}\right) ; 3.19$ and $3.48\left(2 \times \mathrm{m}, 2 \times 1 \mathrm{H}, 17-\mathrm{H}_{2}\right) ; 4.18(\mathrm{~s}$, $1 \mathrm{H}, 17-\mathrm{OH}) ; 6.41(\mathrm{~s}, 1 \mathrm{H}, 4-\mathrm{H}) ; 6.50(\mathrm{dd}, 1 \mathrm{H}, J=1.76 \mathrm{~Hz}, J=8.2 \mathrm{~Hz}, 2-\mathrm{H}) ; 7.04(\mathrm{~d}, 1 \mathrm{H}, J=8.5 \mathrm{~Hz}, 1-\mathrm{H})$; 8.96 (s, 1H, 3-OH), ${ }^{13} \mathrm{C}-\mathrm{NMR} \delta$ ppm 14.4 (C-16a); 25.0; 25.2 (C-18); 26.3; 27.4; 29.8; 30.3; 35.1; 38.0; 41.3; 43.2; 50.8; 61.5 (C-17); 112.7 (C-2); 114.5 (C-4); 126.0 (C-1); 130.6 (C-10); 136.9 (C-5); 154.8 (C-3).

\subsubsection{General Procedure for the Synthesis of 3-(Prop-2-inyloxy)-D-secoestrones 9, 10}

3-Hydroxy-D-secoalcohol 7 or 8 (288 mg, $1.00 \mathrm{mmol})$ was dissolved in acetone $(10 \mathrm{~mL})$, propargyl bromide (0.17 $\mathrm{mL}$ (80 wt \% in toluene), $1.50 \mathrm{mmol})$ and potassium carbonate $(968 \mathrm{mg}, 7.00 \mathrm{mmol})$ were added. The reaction mixture was stirred at $70{ }^{\circ} \mathrm{C}$ for $24 \mathrm{~h}$, the solvent was evaporated off, and the residue was subjected to flash chromatography with $2 \%$ ethyl acetate $/ 98 \%$ dichloromethane as eluent.

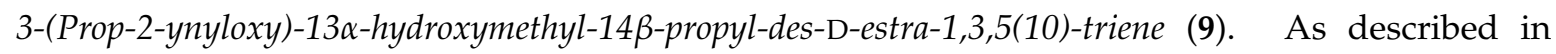
Section 4.2.3, 3-hydroxy-D-secoalcohol 7 (288 mg, $1.00 \mathrm{mmol})$ was reacted with propargyl bromide (0.17 $\mathrm{mL}$ (80 wt \% in toluene), $1.50 \mathrm{mmol})$. Compound 9 was obtained as a white solid $(280 \mathrm{mg}, 86 \%)$. $\mathrm{Mp} 41-43{ }^{\circ} \mathrm{C}, \mathrm{R}_{\mathrm{f}}=0.40$ (A). Anal. Calcd. for $\mathrm{C}_{22} \mathrm{H}_{30} \mathrm{O}_{2}: \mathrm{C}, 80.94 ; \mathrm{H}, 9.26$. Found: C, 81.02; $\mathrm{H}, 9.35$. ${ }^{1} \mathrm{H}-\mathrm{NMR} \delta$ ppm $0.78\left(\mathrm{~s}, 3 \mathrm{H}, 18-\mathrm{H}_{3}\right) ; 0.92\left(\mathrm{t}, 3 \mathrm{H}, \mathrm{J}=6.9 \mathrm{~Hz}, 16 \mathrm{a}-\mathrm{H}_{3}\right) ; 2.50(\mathrm{~s}, 1 \mathrm{H}, \mathrm{C} \equiv \mathrm{CH}) ; 2.86(\mathrm{~m}, 2 \mathrm{H}$, $\left.6-\mathrm{H}_{2}\right) ; 3.34$ and $3.52\left(2 \times \mathrm{d}, 2 \times 1 \mathrm{H}, \mathrm{J}=10.9 \mathrm{~Hz}, 17-\mathrm{H}_{2}\right) ; 4.66\left(\mathrm{~s}, 2 \mathrm{H}, \mathrm{OCH}_{2}\right) ; 6.70(\mathrm{~d}, 1 \mathrm{H}, \mathrm{J}=2.3 \mathrm{~Hz}, 4-\mathrm{H})$; $6.79(\mathrm{dd}, 1 \mathrm{H}, J=8.5 \mathrm{~Hz}, J=2.3 \mathrm{~Hz}, 2-\mathrm{H}) ; 7.24(\mathrm{~d}, 1 \mathrm{H}, J=8.5 \mathrm{~Hz}, 1-\mathrm{H}),{ }^{13} \mathrm{C}-\mathrm{NMR} \delta \mathrm{ppm} 14.7$ (C-16a); 15.9 (C-18); $25.0 ; 26.4 ; 27.5 ; 30.7 ; 31.2 ; 35.6 ; 38.7 ; 41.7 ; 43.5 ; 45.2 ; 55.7$ and $71.3\left(2 \times \mathrm{OCH}_{2}\right) ; 74.9(\mathrm{C} \equiv \underline{\mathrm{CH}})$; $78.5(\mathrm{C} \equiv \mathrm{CH}) ; 112.4$ (C-2); 114.5 (C-4); 126.6 (C-1); 133.8 (C-10); 138.1 (C-5); 155.4 (C-3).

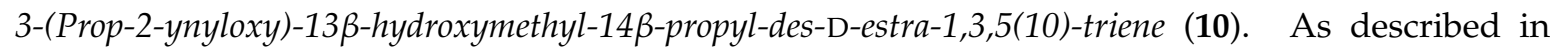
Section 4.2.3, 3-hydroxy-D-secoalcohol $8(288 \mathrm{mg}, 1.00 \mathrm{mmol})$ was reacted with propargylbromide (0.17 mL (80 wt \% in toluene), $1.50 \mathrm{mmol})$. Compound 10 was obtained as a white solid $(271 \mathrm{mg}, 83 \%)$. $\mathrm{Mp} \mathrm{41-43}{ }^{\circ} \mathrm{C}, \mathrm{R}_{\mathrm{f}}=0.50$ (A). Anal. Calcd. for $\mathrm{C}_{22} \mathrm{H}_{30} \mathrm{O}_{2}: \mathrm{C}, 80.94 ; \mathrm{H}, 9.26$. Found: C, 80.87; $\mathrm{H}, 9.42$. ${ }^{1} \mathrm{H}-\mathrm{NMR} \delta$ ppm $0.92\left(\mathrm{t}, 3 \mathrm{H}, J=6.9 \mathrm{~Hz}, 16 \mathrm{a}-\mathrm{H}_{3}\right) ; 1.03\left(\mathrm{~s}, 3 \mathrm{H}, 18-\mathrm{H}_{3}\right) ; 2.50(\mathrm{~s}, 1 \mathrm{H}, \mathrm{C} \equiv \mathrm{CH}) ; 2.84(\mathrm{~m}, 2 \mathrm{H}$, $\left.6-\mathrm{H}_{2}\right) ; 3.47$ and $3.73\left(2 \times \mathrm{d}, 2 \times 1 \mathrm{H}, \mathrm{J}=10.9 \mathrm{~Hz}, 17-\mathrm{H}_{2}\right) ; 4.65\left(\mathrm{~s}, 2 \mathrm{H}, \mathrm{OCH}_{2}\right) ; 6.68(\mathrm{~d}, 1 \mathrm{H}, \mathrm{J}=2.3 \mathrm{~Hz}, 4-\mathrm{H})$; $6.78(\mathrm{dd}, 1 \mathrm{H}, J=8.5 \mathrm{~Hz}, J=2.3 \mathrm{~Hz}, 2-\mathrm{H}) ; 7.22(\mathrm{~d}, 1 \mathrm{H}, J=8.5 \mathrm{~Hz}, 1-\mathrm{H}),{ }^{13} \mathrm{C}-\mathrm{NMR} \delta \mathrm{ppm} 14.6(\mathrm{C}-16 \mathrm{a})$; 24.9 (C-18); 25.5; 26.6; 27.7; 30.6; 31.0; 35.2; 38.6; 41.7; 43.7; 51.4; 55.7 and $64.1\left(2 \times \mathrm{OCH}_{2}\right) ; 75.2(\mathrm{C} \equiv \underline{\mathrm{CH}})$; 78.9 ( $\underline{\mathrm{C}} \mathrm{CH}) ; 112.4(\mathrm{C}-2) ; 114.5$ (C-4); 126.5 (C-1); 133.8 (C-10); 137.9 (C-5); $155.4(\mathrm{C}-3)$.

\subsubsection{General Procedure for the "Click" Reaction}

To a stirred solution of 3-(prop-2-inlyoxy)-D-secoalcohol 9 or 10 (326 mg, $1.00 \mathrm{mmol}$ ) in toluene (5 mL), $\mathrm{PPh}_{3}(52 \mathrm{mg}, 0.20 \mathrm{mmol}), \mathrm{CuI}(19 \mathrm{mg}, 0.10 \mathrm{mmol}), \mathrm{DIPEA}(0.52 \mathrm{ml}, 3.00 \mathrm{mmol})$ and the appropriate benzyl azide 11 (1 equiv., see [28-31] for their preparation) were added. The reaction mixture was refluxed for $2 \mathrm{~h}$, allowed to cool and evaporated in vacuo. The residue 12a-e, 13a-e was purified by flash chromatography with $10 \%$ ethyl acetate $/ 90 \%$ dichloromethane as eluent.

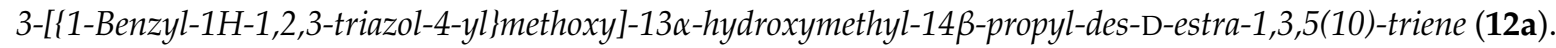
As described in Section 4.2.4, alkyne $9(326 \mathrm{mg}, 1.00 \mathrm{mmol})$ was reacted with benzyl azide $11 \mathrm{a}(133 \mathrm{mg}$, $1.0 \mathrm{mmol})$. Yield: $428 \mathrm{mg}(93 \%)$. Mp $41-43{ }^{\circ} \mathrm{C}, \mathrm{R}_{\mathrm{f}}=0.46$ (B). Anal. Calcd. for $\mathrm{C}_{29} \mathrm{H}_{37} \mathrm{~N}_{3} \mathrm{O}_{2}: \mathrm{C}_{7} 75.78$; H, 8.11. Found: C, 75.94; H, 8.25. ${ }^{1} \mathrm{H}-\mathrm{NMR} \delta \mathrm{ppm} 0.77\left(\mathrm{~s}, 3 \mathrm{H}, 18-\mathrm{H}_{3}\right) ; 0.92\left(\mathrm{t}, 3 \mathrm{H}, J=6.9 \mathrm{~Hz}, 16 \mathrm{a}-\mathrm{H}_{3}\right)$; 
$2.84\left(\mathrm{~m}, 2 \mathrm{H}, 6-\mathrm{H}_{2}\right) ; 3.34$ and $3.52\left(2 \times \mathrm{d}, 2 \times 1 \mathrm{H}, J=10.9 \mathrm{~Hz}, 17-\mathrm{H}_{2}\right) ; 5.16\left(\mathrm{~s}, 2 \mathrm{H}, \mathrm{OCH}_{2}\right) ; 5.53(\mathrm{~s}, 2 \mathrm{H}$, $\left.\mathrm{NCH}_{2}\right) ; 6.69(\mathrm{~d}, 1 \mathrm{H}, J=2.3 \mathrm{~Hz}, 4-\mathrm{H}) ; 6.77(\mathrm{dd}, 1 \mathrm{H}, J=8.5 \mathrm{~Hz}, J=2.3 \mathrm{~Hz}, 2-\mathrm{H}) ; 7.21(\mathrm{~d}, 1 \mathrm{H}, J=8.5 \mathrm{~Hz}$, $1-\mathrm{H}) ; 7.28\left(\mathrm{dd}, 2 \mathrm{H}, J=8.6 \mathrm{~Hz}, J=2.9 \mathrm{~Hz}, 2^{\prime}-\mathrm{H}\right.$ and $\left.6^{\prime}-\mathrm{H}\right), 7.38$ (overlapping multiplets, $3 \mathrm{H}, 3^{\prime}-\mathrm{H}, 4^{\prime}-\mathrm{H}$ and $\left.5^{\prime}-\mathrm{H}\right) ; 7.52(\mathrm{~s}, 1 \mathrm{H}, \mathrm{C}=\mathrm{CH}),{ }^{13} \mathrm{C}-\mathrm{NMR} \delta \mathrm{ppm} 14.6$ (C-18); 16.0 (C-16a); 25.0; 26.4; 27.4; 30.6; 31.2; 35.6; 38.7; 41.7; 43.5; 45.2; $54.2\left(\mathrm{NCH}_{2}\right) ; 62.1\left(\mathrm{OCH}_{2}\right) ; 71.3(\mathrm{C}-17) ; 112.4(\mathrm{C}-2) ; 114.4(\mathrm{C}-4) ; 122.5(\mathrm{C}=\mathrm{CH}) ; 126.6$ (C-1); 128.1 (2C: C-3', $\left.5^{\prime}\right) ; 128.8\left(\mathrm{C}-4^{\prime}\right) ; 129.1$ (2C: C-2', $\left.6^{\prime}\right) ; 133.5$ (C-10); $134.4\left(\mathrm{C}-1^{\prime}\right) ; 138.1$ (C-5); 144.9 $(\mathrm{C}=\mathrm{CH}) ; 156.0(\mathrm{C}-3)$.

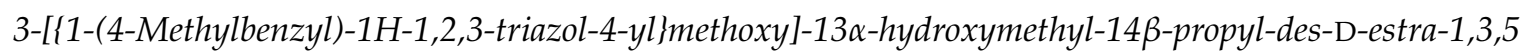
(10)-triene (12b). As described in Section 4.2.4, alkyne $9(326 \mathrm{mg}, 1.00 \mathrm{mmol}$ ) was reacted with 4-methylbenzyl azide $11 \mathrm{~b}(147 \mathrm{mg}, 1.00 \mathrm{mmol})$. Yield: $436 \mathrm{mg}(92 \%) . \mathrm{Mp} 50-52{ }^{\circ} \mathrm{C}, \mathrm{R}_{\mathrm{f}}=0.26$ (B). Anal. Calcd. for $\mathrm{C}_{30} \mathrm{H}_{39} \mathrm{~N}_{3} \mathrm{O}_{2}: \mathrm{C}, 76.07 ; \mathrm{H}, 8.30$. Found: $\mathrm{C}, 75.92 ; \mathrm{H}, 8.54 .{ }^{1} \mathrm{H}-\mathrm{NMR} \delta \mathrm{ppm} 0.77(\mathrm{~s}, 3 \mathrm{H}$, $\left.18-\mathrm{H}_{3}\right) ; 0.91\left(\mathrm{t}, 3 \mathrm{H}, J=6.9 \mathrm{~Hz}, 16 \mathrm{a}-\mathrm{H}_{3}\right) ; 2.35\left(\mathrm{~s}, 3 \mathrm{H}\right.$, tolyl $\left.-\mathrm{CH}_{3}\right) ; 2.83\left(\mathrm{~m}, 2 \mathrm{H}, 6-\mathrm{H}_{2}\right) ; 3.34$ and $3.52(2 \times \mathrm{d}$, $\left.2 \times 1 \mathrm{H}, J=10.9 \mathrm{~Hz}, 17-\mathrm{H}_{2}\right) ; 5.15\left(\mathrm{~s}, 2 \mathrm{H}, \mathrm{OCH}_{2}\right) ; 5.48\left(\mathrm{~s}, 2 \mathrm{H}, \mathrm{NCH}_{2}\right) ; 6.68(\mathrm{~d}, 1 \mathrm{H}, J=2.3 \mathrm{~Hz}, 4-\mathrm{H}) ; 6.76$ $(\mathrm{dd}, 1 \mathrm{H}, J=8.5 \mathrm{~Hz}, J=2.3 \mathrm{~Hz}, 2-\mathrm{H}) ; 7.17-7.20$ (overlapping multiplets, $6 \mathrm{H}, 1-\mathrm{H}, \mathrm{C}=\mathrm{CH}, 2^{\prime}-\mathrm{H}, 3^{\prime}-\mathrm{H}, 5^{\prime}-\mathrm{H}$ and $\left.6^{\prime}-\mathrm{H}\right),{ }^{13} \mathrm{C}-\mathrm{NMR} \delta \mathrm{ppm} 14.6$ (C-18); 15.9 (C-16a); 21.1 (tolyl- $\left.\mathrm{CH}_{3}\right) ; 24.9 ; 26.4 ; 27.4 ; 30.6 ; 31.2 ; 35.6$; $38.7 ; 41.7 ; 43.5 ; 45.3 ; 54.2\left(\mathrm{NCH}_{2}\right) ; 62.1\left(\mathrm{OCH}_{2}\right) ; 71.3(\mathrm{C}-17) ; 112.4(\mathrm{C}-2) ; 114.4(\mathrm{C}-4) ; 122.4(\mathrm{C}=\mathrm{CH}) ; 126.5$ (C-1); $128.2\left(2 \mathrm{C}: \mathrm{C}-3^{\prime}, 5^{\prime}\right) ; 129.7\left(2 \mathrm{C}: \mathrm{C}-2^{\prime}, 6^{\prime}\right) ; 131.3$ and $133.5(\mathrm{C}-10$ and C-4' $) ; 138.1(\mathrm{C}-5) ; 138.7\left(\mathrm{C}-1^{\prime}\right)$; $144.7(\underline{\mathrm{C}}=\mathrm{CH}) ; 156.0(\mathrm{C}-3)$.

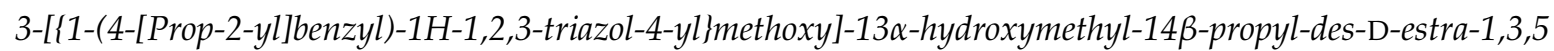
(10)-triene (12c). As described in Section 4.2.4, alkyne 9 (326 mg, $1.00 \mathrm{mmol}$ ) was reacted with 4-(prop-2-yl)-benzyl azide 11c (175 mg, $1.00 \mathrm{mmol}$ ). Yield: $452 \mathrm{mg}(90 \%) . \mathrm{Mp} 41-43^{\circ} \mathrm{C}, \mathrm{R}_{\mathrm{f}}=0.30$ (B). Anal. Calcd. for $\mathrm{C}_{32} \mathrm{H}_{43} \mathrm{~N}_{3} \mathrm{O}_{2}: \mathrm{C}, 76.61 ; \mathrm{H}, 8.64$. Found: $\mathrm{C}, 76.85 ; \mathrm{H}, 8.76 .{ }^{1} \mathrm{H}-\mathrm{NMR} \delta \mathrm{ppm} 0.77(\mathrm{~s}, 3 \mathrm{H}$, $\left.18-\mathrm{H}_{3}\right) ; 0.91\left(\mathrm{t}, 3 \mathrm{H}, J=6.9 \mathrm{~Hz}, 16 \mathrm{a}-\mathrm{H}_{3}\right) ; 1.24\left(\mathrm{~d}, 6 \mathrm{H}, 2 \times\right.$ prop-2-yl- $\left.\mathrm{CH}_{3}\right) ; 2.83\left(\mathrm{~m}, 2 \mathrm{H}, 6-\mathrm{H}_{2}\right) ; 3.33$ and 3.52 $\left(2 \times \mathrm{d}, 2 \times 1 \mathrm{H}, J=10.9 \mathrm{~Hz}, 17-\mathrm{H}_{2}\right) ; 5.19\left(\mathrm{~s}, 2 \mathrm{H}, \mathrm{OCH}_{2}\right) ; 5.50\left(\mathrm{~s}, 2 \mathrm{H}, \mathrm{NCH}_{2}\right) ; 6.68(\mathrm{~d}, 1 \mathrm{H}, J=2.3 \mathrm{~Hz}, 4-\mathrm{H})$; $6.75(\mathrm{dd}, 1 \mathrm{H}, J=8.5 \mathrm{~Hz}, J=2.3 \mathrm{~Hz}, 2-\mathrm{H}) ; 7.22-7.24$ (overlapping multiplets, 5H, 1-H, $2^{\prime}-\mathrm{H}, 3^{\prime}-\mathrm{H}, 5^{\prime}-\mathrm{H}$ and $\left.6^{\prime}-\mathrm{H}\right) ; 7.55(\mathrm{~s}, 1 \mathrm{H}, \mathrm{C}=\mathrm{CH}),{ }^{13} \mathrm{C}-\mathrm{NMR} \delta \mathrm{ppm} 14.6$ and $15.9(\mathrm{C}-18$ and $\mathrm{C}-16 \mathrm{a}) ; 23.8\left(2 \mathrm{C}: \mathrm{CH}\left(\mathrm{CH}_{3}\right)_{2}\right)$; $24.9 ; 26.4 ; 27.4 ; 30.6 ; 31.2 ; 33.8\left(\underline{\mathrm{CH}}\left(\mathrm{CH}_{3}\right)_{2}\right) ; 35.6 ; 38.7 ; 41.7 ; 43.5 ; 45.2 ; 54.0\left(\mathrm{NCH}_{2}\right) ; 62.0\left(\mathrm{OCH}_{2}\right) ; 71.2$ (C-17); $112.3(\mathrm{C}-2) ; 114.3(\mathrm{C}-4) ; 122.5(\mathrm{C}=\mathrm{CH}) ; 126.5(\mathrm{C}-1) ; 127.1$ (2C: $\left.\mathrm{C}-3^{\prime}, 5^{\prime}\right) ; 128.2\left(2 \mathrm{C}: \mathrm{C}-2^{\prime}, 6^{\prime}\right) ; 131.7$ (C-1'); 133.5 (C-10); 138.1 (C-5); 144.7 (C-4'); 149.6 ( $\mathrm{C}=\mathrm{CH}) ; 156.1$ (C-3).

3-[\{1-(4-tert-Butylbenzyl)-1H-1,2,3-triazol-4-yl\}methoxy]-13 $\alpha$-hydroxymethyl-14 $\beta$-propyl-des-D-estra-1,3,5 (10)-triene (12d). As described in Section 4.2.4, alkyne $9(326 \mathrm{mg}, 1.00 \mathrm{mmol}$ ) was reacted with 4-tert-butylbenzyl azide 11d (189 mg, $1.00 \mathrm{mmol})$. Yield: $475 \mathrm{mg}(92 \%) . \mathrm{Mp} 58-60{ }^{\circ} \mathrm{C}, \mathrm{R}_{\mathrm{f}}=0.32(\mathrm{~B})$. Anal. Calcd. for $\mathrm{C}_{33} \mathrm{H}_{45} \mathrm{~N}_{3} \mathrm{O}_{2}: \mathrm{C}, 76.85 ; \mathrm{H}, 8.79$. Found: $\mathrm{C}, 75.98 ; \mathrm{H}, 8.95 .{ }^{1} \mathrm{H}-\mathrm{NMR} \delta \mathrm{ppm} 0.77(\mathrm{~s}, 3 \mathrm{H}$, $\left.18-\mathrm{H}_{3}\right) ; 0.91\left(\mathrm{t}, 3 \mathrm{H}, J=6.9 \mathrm{~Hz}, 16 \mathrm{a}-\mathrm{H}_{3}\right) ; 1.31\left(\mathrm{~s}, 9 \mathrm{H}, 3 \times{ }^{\mathrm{t}} \mathrm{Bu}^{\left.-\mathrm{CH}_{3}\right)} ; 2.83\left(\mathrm{~m}, 2 \mathrm{H}, 6-\mathrm{H}_{2}\right) ; 3.33\right.$ and $3.52(2 \times \mathrm{d}$, $\left.2 \times 1 \mathrm{H}, J=10.9 \mathrm{~Hz}, 17-\mathrm{H}_{2}\right) ; 5.18\left(\mathrm{~s}, 2 \mathrm{H}, \mathrm{OCH}_{2}\right) ; 5.50\left(\mathrm{~s}, 2 \mathrm{H}, \mathrm{NCH}_{2}\right) ; 6.68(\mathrm{~d}, 1 \mathrm{H}, J=2.3 \mathrm{~Hz}, 4-\mathrm{H}) ; 6.77$ $(\mathrm{dd}, 1 \mathrm{H}, J=8.5 \mathrm{~Hz}, J=2.3 \mathrm{~Hz}, 2-\mathrm{H}) ; 7.20-7.24$ (overlapping multiplets, $3 \mathrm{H}, 1-\mathrm{H}, 2^{\prime}-\mathrm{H}$ and $6^{\prime}-\mathrm{H}$ ); 7.39 (d, $2 \mathrm{H}, J=8.1 \mathrm{~Hz}, 3^{\prime}-\mathrm{H}$ and $\left.5^{\prime}-\mathrm{H}\right) ; 7.54(\mathrm{~s}, 1 \mathrm{H}, \mathrm{C}=\mathrm{CH}),{ }^{13} \mathrm{C}-\mathrm{NMR} \delta \mathrm{ppm} 14.7$ and 15.9 (C-18 and C-16a); $24.9 ; 26.4 ; 27.4 ; 30.7 ; 31.1\left(3 \mathrm{C}: \mathrm{C}\left(\mathrm{CH}_{3}\right)_{3}\right) ; 31.2 ; 34.6\left(\underline{\mathrm{C}}\left(\mathrm{CH}_{3}\right)_{3}\right) ; 35.6 ; 38.7 ; 41.7 ; 43.5 ; 45.2 ; 54.0\left(\mathrm{NCH}_{2}\right)$; $62.1\left(\mathrm{OCH}_{2}\right) ; 71.3(\mathrm{C}-17) ; 112.4(\mathrm{C}-2) ; 114.4(\mathrm{C}-4) ; 122.5(\mathrm{C}=\mathrm{CH}) ; 126.0\left(2 \mathrm{C}: \mathrm{C}^{\prime} 3^{\prime}, 5^{\prime}\right) ; 126.6(\mathrm{C}-1) ; 127.9$ (2C: $\left.\mathrm{C}-2^{\prime}, 6^{\prime}\right) ; 131.3\left(\mathrm{C}-1^{\prime}\right) ; 133.5(\mathrm{C}-10) ; 138.1(\mathrm{C}-5) ; 144.8\left(\mathrm{C}-4^{\prime}\right) ; 151.9(\underline{\mathrm{C}}=\mathrm{CH}) ; 156.0(\mathrm{C}-3)$.

3-[\{1-(4-Nitrobenzyl)-1H-1,2,3-triazol-4-yl\}methoxy]-13 $\alpha$-hydroxymethyl-14 $\beta$-propyl-des-D-estra-1,3,5(10) -triene (12e). As described in Section 4.2.4, alkyne 9 (326 mg, $1.00 \mathrm{mmol}$ ) was reacted with 4-nitrobenzyl azide 11e (178 mg, $1.00 \mathrm{mmol})$. Yield: $475 \mathrm{mg}, 94 \%)$. Mp 65-67 ${ }^{\circ} \mathrm{C}, \mathrm{R}_{\mathrm{f}}=0.20$ (B). Anal. Calcd. for $\mathrm{C}_{29} \mathrm{H}_{36} \mathrm{~N}_{4} \mathrm{O}_{4}: \mathrm{C}, 69.02 ; \mathrm{H}, 7.19$. Found: $\mathrm{C}, 69.15 ; \mathrm{H}, 7.02 .{ }^{1} \mathrm{H}-\mathrm{NMR} \delta \mathrm{ppm} 0.77\left(\mathrm{~s}, 3 \mathrm{H}, 18-\mathrm{H}_{3}\right) ; 0.91(\mathrm{t}$, $\left.3 \mathrm{H}, J=6.9 \mathrm{~Hz}, 16 \mathrm{a}-\mathrm{H}_{3}\right) ; 2.83\left(\mathrm{~m}, 2 \mathrm{H}, 6-\mathrm{H}_{2}\right) ; 3.34$ and $3.52\left(2 \times \mathrm{d}, 2 \times 1 \mathrm{H}, J=10.9 \mathrm{~Hz}, 17-\mathrm{H}_{2}\right) ; 5.19(\mathrm{~s}, 2 \mathrm{H}$, $\left.\mathrm{OCH}_{2}\right) ; 5.64\left(\mathrm{~s}, 2 \mathrm{H}, \mathrm{NCH}_{2}\right) ; 6.67(\mathrm{~d}, 1 \mathrm{H}, J=2.3 \mathrm{~Hz}, 4-\mathrm{H}) ; 6.76(\mathrm{dd}, 1 \mathrm{H}, J=8.5 \mathrm{~Hz}, J=2.3 \mathrm{~Hz}, 2-\mathrm{H}) ; 7.21$ $(\mathrm{d}, 1 \mathrm{H}, J=8.5 \mathrm{~Hz}, 1-\mathrm{H}) ; 7.40\left(\mathrm{~d}, 2 \mathrm{H}, J=8.6 \mathrm{~Hz}, 2^{\prime}-\mathrm{H}, 6^{\prime}-\mathrm{H}\right) ; 7.62(\mathrm{~s}, 1 \mathrm{H}, \mathrm{C}=\mathrm{CH}) ; 8.22(\mathrm{~d}, J=8.6 \mathrm{~Hz}, 2 \mathrm{H}$, $\left.3^{\prime}-\mathrm{H}, 5^{\prime}-\mathrm{H}\right),{ }^{13} \mathrm{C}-\mathrm{NMR} \delta$ ppm 14.6 (C-18); 15.9 (C-16a); 24.9; 26.4; 27.4; 30.7; 31.2; 35.6; 38.7; 41.7; 43.5; 
45.2; $53.1\left(\mathrm{NCH}_{2}\right) ; 62.0\left(\mathrm{OCH}_{2}\right) ; 71.2(\mathrm{C}-17) ; 112.3(\mathrm{C}-2) ; 114.3(\mathrm{C}-4) ; 122.8(\mathrm{CH}=\mathrm{C}) ; 124.3\left(2 \mathrm{C}: \mathrm{C}^{\prime} 3^{\prime}, 5^{\prime}\right)$; $126.6(\mathrm{C}-1) ; 128.6\left(2 \mathrm{C}: \mathrm{C}-2^{\prime}, 6^{\prime}\right) ; 133.7(\mathrm{C}-10) ; 138.2(\mathrm{C}-5) ; 141.5$ and $145.5\left(\mathrm{C}-1^{\prime}\right.$ and $\left.\mathrm{C}=\mathrm{CH}\right) ; 148.1\left(\mathrm{C}-4^{\prime}\right)$; 155.9 (C-3).

3-[\{1-Benzyl-1H-1,2,3-triazol-4-yl\}methoxy]-13 $\beta$-hydroxymethyl-14 $\beta$-propyl-des-D-estra-1,3,5(10)-triene (13a). As described in Section 4.2.4, alkyne $10(326 \mathrm{mg}, 1.00 \mathrm{mmol})$ was reacted with benzyl azide 11a (133 mg, 1.00 mmol). Yield: $437 \mathrm{mg}(95 \%)$. Oil, $\mathrm{R}_{\mathrm{f}}=0.19$ (B). Anal. Calcd. for $\mathrm{C}_{29} \mathrm{H}_{37} \mathrm{~N}_{3} \mathrm{O}_{2}: \mathrm{C}, 75.78 ; \mathrm{H}$, 8.11. Found: $\mathrm{C}, 75.93 ; \mathrm{H}, 8.02 .{ }^{1} \mathrm{H}-\mathrm{NMR} \delta \mathrm{ppm} 0.89\left(\mathrm{t}, 3 \mathrm{H}, J=7.2 \mathrm{~Hz}, 16 \mathrm{a}-\mathrm{H}_{3}\right) ; 1.00\left(\mathrm{~s}, 3 \mathrm{H}, 18-\mathrm{H}_{3}\right) ; 2.80$ $\left(\mathrm{m}, 2 \mathrm{H}, 6-\mathrm{H}_{2}\right) ; 3.44$ and $3.70\left(2 \times \mathrm{d}, 2 \times 1 \mathrm{H}, J=10.9 \mathrm{~Hz}, 17-\mathrm{H}_{2}\right) ; 5.13\left(\mathrm{~s}, 2 \mathrm{H}, \mathrm{OCH}_{2}\right) ; 5.50\left(\mathrm{~s}, 2 \mathrm{H}, \mathrm{NCH}_{2}\right)$; $6.66(\mathrm{~d}, 1 \mathrm{H}, J=2.4 \mathrm{~Hz}, 4-\mathrm{H}) ; 6.73(\mathrm{dd}, 1 \mathrm{H}, J=8.5 \mathrm{~Hz}, J=2.1 \mathrm{~Hz}, 2-\mathrm{H}) ; 7.16(\mathrm{~d}, 1 \mathrm{H}, J=8.5 \mathrm{~Hz}, 1-\mathrm{H})$; $7.24\left(\mathrm{~d}, 2 \mathrm{H}, J=7.6 \mathrm{~Hz}, 2^{\prime}-\mathrm{H}\right.$ and $\left.6^{\prime}-\mathrm{H}\right), 7.35$ (overlapping multiplets, $3 \mathrm{H}, 3^{\prime}-\mathrm{H}, 4^{\prime}-\mathrm{H}$ and $\left.5^{\prime}-\mathrm{H}\right) ; 7.51$ (s, $1 \mathrm{H}, \mathrm{C}=\mathrm{CH}),{ }^{13} \mathrm{C}-\mathrm{NMR} \delta$ ppm 14.5 (C-16a); 24.9 (C-18); 25.5; 26.6; 27.7; 30.5; 30.9; 35.2; 38.5; 41.6; 43.7; 51.4; $54.2\left(\mathrm{NCH}_{2}\right) ; 62.0$ and $64.0\left(\mathrm{OCH}_{2}\right.$ and C-17); $112.3(\mathrm{C}-2) ; 114.3(\mathrm{C}-4) ; 122.5(\mathrm{C}=\underline{\mathrm{CH}}) ; 126.5(\mathrm{C}-1)$; 128.1 (2C: C-3', $\left.5^{\prime}\right) ; 128.8\left(\mathrm{C}-4^{\prime}\right) ; 129.1\left(2 \mathrm{C}: \mathrm{C}^{\prime} 2^{\prime}, 6^{\prime}\right) ; 133.4(\mathrm{C}-10) ; 134.4\left(\mathrm{C}-1^{\prime}\right) ; 137.9(\mathrm{C}-5) ; 145.0(\underline{\mathrm{C}}=\mathrm{CH})$; $156.0(\mathrm{C}-3)$.

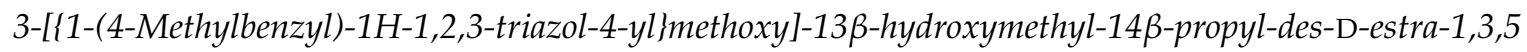
(10)-triene (13b). As described in Section 4.2.4, alkyne $10(326 \mathrm{mg}, 1.00 \mathrm{mmol}$ ) was reacted with 4-methylbenzyl azide $11 \mathrm{~b}(147 \mathrm{mg}, 1.00 \mathrm{mmol})$. Yield: $431 \mathrm{mg}(91 \%) . \mathrm{Mp} 49-51{ }^{\circ} \mathrm{C}, \mathrm{R}_{\mathrm{f}}=0.16(\mathrm{~B})$. Anal. Calcd. for $\mathrm{C}_{30} \mathrm{H}_{39} \mathrm{~N}_{3} \mathrm{O}_{2}: \mathrm{C}, 76.07 ; \mathrm{H}, 8.30$. Found: $\mathrm{C}, 75.94 ; \mathrm{H}, 8.22$. ${ }^{1} \mathrm{H}-\mathrm{NMR} \delta \mathrm{ppm} 0.90(\mathrm{t}$, $\left.3 \mathrm{H}, J=7.5 \mathrm{~Hz}, 16 \mathrm{a}-\mathrm{H}_{3}\right) ; 1.02\left(\mathrm{~s}, 3 \mathrm{H}, 18-\mathrm{H}_{3}\right) ; 2.36\left(\mathrm{~s}, 3 \mathrm{H}\right.$, tolyl- $\left.\mathrm{CH}_{3}\right) ; 2.82\left(\mathrm{~m}, 2 \mathrm{H}, 6-\mathrm{H}_{2}\right) ; 3.47$ and 3.73 $\left(2 \times \mathrm{d}, 2 \times 1 \mathrm{H}, J=10.9 \mathrm{~Hz}, 17-\mathrm{H}_{2}\right) ; 5.14\left(\mathrm{~s}, 2 \mathrm{H}, \mathrm{OCH}_{2}\right) ; 5.48\left(\mathrm{~s}, 2 \mathrm{H}, \mathrm{NCH}_{2}\right) ; 6.68(\mathrm{~s}, 1 \mathrm{H}, 4-\mathrm{H}) ; 6.76(\mathrm{~d}, 1 \mathrm{H}$, $J=7.8 \mathrm{~Hz}, 2-\mathrm{H}$ ); 7.17 (overlapping multiplets, $\left.6 \mathrm{H}, 1-\mathrm{H}, \mathrm{C}=\mathrm{CH}, 2^{\prime}, 3^{\prime}, 5^{\prime}, 6^{\prime}-\mathrm{H}\right),{ }^{13} \mathrm{C}-\mathrm{NMR} \delta \mathrm{ppm} 14.6$ (C-16a); 21.1 (tolyl-CH 3 ); 24.9 (C-18); 25.5; 26.6; 27.7; 30.5; 30.9; 35.2; 38.6; 41.7; 43.7; 51.4; $54.2\left(\mathrm{NCH}_{2}\right)$; 62.0 and $64.1\left(\mathrm{OCH}_{2}\right.$ and C-17); $112.4(\mathrm{C}-2) ; 114.3(\mathrm{C}-4) ; 122.4(\mathrm{C}=\mathrm{CH}) ; 126.5(\mathrm{C}-1) ; 128.2\left(2 \mathrm{C}: \mathrm{C}^{\prime} 3^{\prime}, 5^{\prime}\right)$; $129.8\left(2 \mathrm{C}: \mathrm{C}-2^{\prime}, 6^{\prime}\right) ; 131.3\left(\mathrm{C}-4^{\prime}\right) ; 133.4(\mathrm{C}-10) ; 137.9(\mathrm{C}-5) ; 138.8\left(\mathrm{C}-1^{\prime}\right) ; 144.7(\mathrm{C}=\mathrm{CH}) ; 156.0(\mathrm{C}-3)$.

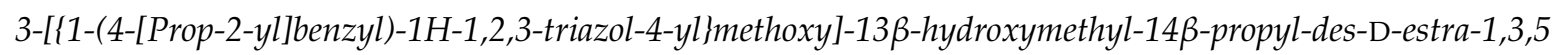
(10)-triene (13c). As described in Section 4.2.4, alkyne $10(326 \mathrm{mg}, 1.00 \mathrm{mmol})$ was reacted with 4-(prop-2-yl)-benzyl azide 11c (175 mg, $1.00 \mathrm{mmol}$ ). Yield: $462 \mathrm{mg}(92 \%) . \mathrm{Mp} 47-49^{\circ} \mathrm{C}, \mathrm{R}_{\mathrm{f}}=0.19$ (B). Anal. Calcd. for $\mathrm{C}_{32} \mathrm{H}_{43} \mathrm{~N}_{3} \mathrm{O}_{2}$ : C, 76.61; H, 8.64. Found: $\mathrm{C}, 76.85 ; \mathrm{H}, 8.53 .{ }^{1} \mathrm{H}-\mathrm{NMR} \delta \mathrm{ppm} 0.91(\mathrm{t}, 3 \mathrm{H}$, $\left.J=6.8 \mathrm{~Hz}, 16 \mathrm{a}-\mathrm{H}_{3}\right) ; 1.02\left(\mathrm{~s}, 3 \mathrm{H}, 18-\mathrm{H}_{3}\right) ; 1.24\left(\mathrm{~d}, 2 \times 3 \mathrm{H}, J=11.4 \mathrm{~Hz}, 2 \times\right.$ prop-2-yl- $\left.\mathrm{CH}_{3}\right) ; 2.82(\mathrm{~m}, 2 \mathrm{H}$, 6- $\left.\mathrm{H}_{2}\right) ; 2.90\left(\mathrm{~m}, 1 \mathrm{H}\right.$, prop-2-yl-CH); 3.47 and $3.73\left(2 \times \mathrm{d}, 2 \times 1 \mathrm{H}, J=10.8 \mathrm{~Hz}, 17-\mathrm{H}_{2}\right) ; 5.15\left(\mathrm{~s}, 2 \mathrm{H}, \mathrm{OCH}_{2}\right)$; $5.49\left(\mathrm{~s}, 2 \mathrm{H}, \mathrm{NCH}_{2}\right) ; 6.68(\mathrm{~d}, 1 \mathrm{H}, J=2.2 \mathrm{~Hz}, 4 \mathrm{H}) ; 6.76(\mathrm{dd}, 1 \mathrm{H}, J=8.6 \mathrm{~Hz}, J=2.2 \mathrm{~Hz}, 2-\mathrm{H}) ; 7.19-7.23$ (overlapping multiplets, $\left.5 \mathrm{H}, 1-\mathrm{H}, 2^{\prime}, 3^{\prime}, 5^{\prime}, 6^{\prime}-\mathrm{H}\right) ; 7.57(\mathrm{~s}, 1 \mathrm{H}, \mathrm{C}=\mathrm{CH}),{ }^{13} \mathrm{C}-\mathrm{NMR} \delta$ ppm 14.5 (C-16a); 23.8 (2C: $\left.\mathrm{CH}\left(\mathrm{CH}_{3}\right)_{2}\right) ; 24.8(\mathrm{C}-18) ; 25.5 ; 26.6 ; 27.7 ; 30.6 ; 31.0 ; 33.8\left(\mathrm{CH}\left(\mathrm{CH}_{3}\right)_{2}\right) ; 35.2 ; 38.6 ; 41.7 ; 43.7 ; 51.4 ; 54.2$ $\left(\mathrm{NCH}_{2}\right) ; 62.1\left(\mathrm{OCH}_{2}\right) ; 64.1(\mathrm{C}-17) ; 112.4(\mathrm{C}-2) ; 114.4(\mathrm{C}-4) ; 122.6(\mathrm{C}=\mathrm{CH}) ; 126.5(\mathrm{C}-1) ; 127.2\left(2 \mathrm{C}: \mathrm{C}^{\prime} 3^{\prime}, 5^{\prime}\right)$; 128.2 (2C: $\left.\mathrm{C}-2^{\prime}, 6^{\prime}\right) ; 131.7\left(\mathrm{C}-1^{\prime}\right) ; 133.4(\mathrm{C}-10) ; 137.9(\mathrm{C}-5) ; 149.7\left(\mathrm{C}-4^{\prime}\right) ; 150.1(\mathrm{C}=\mathrm{CH}) ; 156.0(\mathrm{C}-3)$.

3-[\{1-(4-tert-Butylbenzyl)-1H-1,2,3-triazol-4-yl\}methoxy]-13 $\beta$-hydroxymethyl-14 $\beta$-propyl-des-D-estra-1,3,5 (10)-triene (13d). As described in Section 4.2.4, alkyne $10(326 \mathrm{mg}, 1.00 \mathrm{mmol})$ was reacted with 4-tert-butylbenzyl azide 11d (189 mg, $1.00 \mathrm{mmol})$. Yield: $470 \mathrm{mg}(91 \%) . \mathrm{Mp} 58-60{ }^{\circ} \mathrm{C}, \mathrm{R}_{\mathrm{f}}=0.32(\mathrm{~B})$. Anal. Calcd. for $\mathrm{C}_{33} \mathrm{H}_{45} \mathrm{~N}_{3} \mathrm{O}_{2}$ : C, 76.85; H, 8.79. Found: $\mathrm{C}, 76.72 ; \mathrm{H}, 8.90 .{ }^{1} \mathrm{H} \mathrm{NMR} \delta \mathrm{ppm} 0.91(\mathrm{t}, 3 \mathrm{H}$, $\left.J=7.2 \mathrm{~Hz}, 16 \mathrm{a}-\mathrm{H}_{3}\right) ; 1.02\left(\mathrm{~s}, 3 \mathrm{H}, 18-\mathrm{H}_{3}\right) ; 1.32\left(\mathrm{~s}, 3 \times 3 \mathrm{H}, 3 \times{ }^{\mathrm{t}} \mathrm{Bu}^{\left.-\mathrm{CH}_{3}\right)} ; 2.82\left(\mathrm{~m}, 2 \mathrm{H}, 6-\mathrm{H}_{2}\right) ; 3.47\right.$ and 3.73 $\left(2 \times \mathrm{d}, 2 \times 1 \mathrm{H}, J=10.9 \mathrm{~Hz}, 17-\mathrm{H}_{2}\right) ; 5.16\left(\mathrm{~s}, 2 \mathrm{H}, \mathrm{OCH}_{2}\right) ; 5.49\left(\mathrm{~s}, 2 \mathrm{H}, \mathrm{NCH}_{2}\right) ; 6.67(\mathrm{~d}, 1 \mathrm{H}, J=2.2 \mathrm{~Hz}, 4 \mathrm{H})$; $6.76(\mathrm{dd}, 1 \mathrm{H}, J=8.6 \mathrm{~Hz}, J=2.2 \mathrm{~Hz}, 2-\mathrm{H}) ; 7.18(\mathrm{~d}, 1 \mathrm{H}, J=8.6 \mathrm{~Hz}, 1-\mathrm{H}) ; 7.21\left(\mathrm{~d}, 2 \mathrm{H}, J=8.2 \mathrm{~Hz}, 2^{\prime}, 6^{\prime}-\mathrm{H}\right)$; $7.39\left(\mathrm{~d}, 2 \mathrm{H}, J=8.2 \mathrm{~Hz}, 3^{\prime}, 5^{\prime}-\mathrm{H}\right) ; 7.54(\mathrm{~s}, 1 \mathrm{H}, \mathrm{C}=\mathrm{CH}),{ }^{13} \mathrm{C}-\mathrm{NMR} \delta \mathrm{ppm} 14.5$ (C-16a); 24.9 (C-18); 25.5;

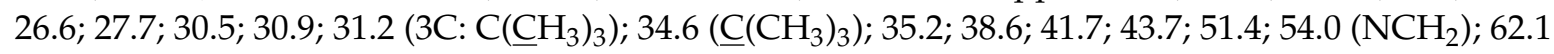
$\left(\mathrm{OCH}_{2}\right) ; 64.1(\mathrm{C}-17) ; 112.4(\mathrm{C}-2) ; 114.3(\mathrm{C}-4) ; 122.6(\mathrm{C}=\mathrm{CH}) ; 126.0\left(2 \mathrm{C}: \mathrm{C}^{\prime} 3^{\prime}, 5^{\prime}\right) ; 126.5(\mathrm{C}-1) ; 127.9(2 \mathrm{C}:$ $\left.\mathrm{C}-2^{\prime}, 6^{\prime}\right) ; 131.3\left(\mathrm{C}-1^{\prime}\right) ; 133.4(\mathrm{C}-10) ; 137.9(\mathrm{C}-5) ; 144.7\left(\mathrm{C}-4^{\prime}\right) ; 151.9$ ( $\left.\mathrm{C}=\mathrm{CH}\right) ; 156.0(\mathrm{C}-3)$.

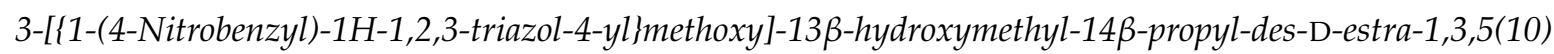
-triene (13e). As described in Section 4.2.4, alkyne $10(326 \mathrm{mg}, 1.00 \mathrm{mmol})$ was reacted with 4-nitrobenzyl azide 11e (178 mg, $1.00 \mathrm{mmol})$. Yield: $475 \mathrm{mg}, 94 \%)$. Mp 50-52 ${ }^{\circ} \mathrm{C}, \mathrm{R}_{\mathrm{f}}=0.12$ (B). Anal. 
Calcd. for $\mathrm{C}_{29} \mathrm{H}_{36} \mathrm{~N}_{4} \mathrm{O}_{4}$ : C, 69.02; H, 7.19. Found: $\mathrm{C}, 69.21 ; \mathrm{H}, 7.05 .{ }^{1} \mathrm{H}-\mathrm{NMR} \delta \mathrm{ppm} 0.91(\mathrm{t}, 3 \mathrm{H}$, $\left.J=6.9 \mathrm{~Hz}, 16 \mathrm{a}-\mathrm{H}_{3}\right) ; 1.02\left(\mathrm{~s}, 3 \mathrm{H}, 18-\mathrm{H}_{3}\right) ; 2.82\left(\mathrm{~m}, 2 \mathrm{H}, 6-\mathrm{H}_{2}\right) ; 3.47$ and $3.73(2 \times \mathrm{d}, 2 \times 1 \mathrm{H}, J=10.9 \mathrm{~Hz}$, $\left.17-\mathrm{H}_{2}\right) ; 5.19\left(\mathrm{~s}, 2 \mathrm{H}, \mathrm{OCH}_{2}\right) ; 5.65\left(\mathrm{~s}, 2 \mathrm{H}, \mathrm{NCH}_{2}\right) ; 6.68(\mathrm{~s}, 1 \mathrm{H}, 4-\mathrm{H}) ; 6.76(\mathrm{~d}, 1 \mathrm{H}, J=8.6 \mathrm{~Hz}, 2-\mathrm{H}) ; 7.20(\mathrm{~d}$, $1 \mathrm{H}, J=8.6 \mathrm{~Hz}, 1-\mathrm{H}) ; 7.40\left(\mathrm{~d}, 2 \mathrm{H}, J=8.3 \mathrm{~Hz}, 2^{\prime}, 6^{\prime}-\mathrm{H}\right) ; 7.64(\mathrm{~s}, 1 \mathrm{H}, \mathrm{C}=\mathrm{CH}) ; 8.23\left(\mathrm{~d}, 2 \mathrm{H}, J=8.5 \mathrm{~Hz}, 3^{\prime}, 5^{\prime}-\mathrm{H}\right)$, ${ }^{13} \mathrm{C}-\mathrm{NMR} \delta$ ppm 14.5 (C-16a); 24.9 (C-18); 25.5; 26.6; 27.7; 30.6; 31.0; 35.2; 38.6; 41.7; 43.7; 51.4; 53.3 $\left(\mathrm{NCH}_{2}\right) ; 62.0\left(\mathrm{OCH}_{2}\right) ; 64.1(\mathrm{C}-17) ; 112.3(\mathrm{C}-2) ; 114.4(\mathrm{C}-4) ; 124.3\left(2 \mathrm{C}: \mathrm{C}-3^{\prime}, 5^{\prime}\right) ; 124.8(\mathrm{C}=\underline{\mathrm{CH}}) ; 126.6(\mathrm{C}-1)$; 128.6 (2C: $\left.\mathrm{C}-2^{\prime}, 6^{\prime}\right) ; 133.6$ (C-10); $138.0(\mathrm{C}-5) ; 141.4\left(\mathrm{C}-1^{\prime}\right) ; 144.0(\mathrm{C}=\mathrm{CH}) ; 144.8\left(\mathrm{C}-4^{\prime}\right) ; 155.9(\mathrm{C}-3)$.

\subsection{Determination of Antiproliferative Activities}

The antiproliferative properties of the prepared triazoles $\mathbf{1 2 a}-\mathbf{e}$ or $\mathbf{1 3 a}-\mathbf{e}$ and compounds $\mathbf{1 , 6} \mathbf{6} \mathbf{- 1 0}$ were determined on a panel of human adherent gynecological cancer cell lines. MCF-7, MDA-MB-231, MDA-MB-361 and T47D were isolated from breast cancers differing in biochemical background, while HeLa, $\mathrm{SiHa}$ and C33A cells were from cervical cancers of various pathological histories, and A2780 cells were isolated from ovarian cancer. Non-cancerous human fibroblast cells (MRC-5) was additionally used to assess the cancer selectivity of the most effective compound. All cell lines were purchased from European Collection of Cell Cultures (ECCAC, Salisbury, UK) except for SiHa and C33A, which were obtained from LGC Standards GmbH (Wesel, Germany). Cells were cultivated in minimal essential medium supplemented with $10 \%$ fetal bovine serum, $1 \%$ non-essential amino acids and an antibiotic-antimycotic mixture. All media and supplements were obtained from Lonza Group Ltd., (Basel, Switzerland). Near-confluent cancer cells were seeded onto a 96-well microplate (5000 cells/well except for C33A and MDA-MB-361, which were seeded at 10,000/well) and, after overnight standing, $200 \mu \mathrm{L}$ new medium, containing the tested compounds at 10 and $30 \mu \mathrm{M}$, was added. After incubation for $72 \mathrm{~h}$ at $37^{\circ} \mathrm{C}$ in humidified air containing $5 \% \mathrm{CO}_{2}$, the living cells were assayed by the addition of $20 \mu \mathrm{L}$ of $5 \mathrm{mg} / \mathrm{ml}$ 3-(4,5-dimethylthiazol-2-yl)-2,5-diphenyltetrazolium bromide (MTT) solution. MTT was converted by intact mitochondrial reductase and precipitated as purple crystals during a 4-h contact period. The medium was next removed and the precipitated formazan crystals were dissolved in $100 \mu \mathrm{L}$ of DMSO during a 60-min period of shaking at $37^{\circ} \mathrm{C}$.

Finally, the reduced MTT was assayed at $545 \mathrm{~nm}$, using a microplate reader; wells with untreated cells served as control [32]. In the case of the most active compounds (i.e., higher than $70 \%$ growth inhibition at $30 \mu \mathrm{M}$ ), the assays were repeated with a set of dilutions, sigmoidal dose-response curves were fitted to the determined data and the $\mathrm{IC}_{50}$ values (the concentration at which the extent of cell proliferation was half that of the untreated control) were calculated by means of GraphPad Prism 4.0 (GraphPad Software, San Diego, CA, USA). All in vitro experiments were carried out on two microplates with at least five parallel wells. Stock solutions of the tested substances $(10 \mathrm{mM})$ were prepared in DMSO. The highest DMSO content of the medium $(0.3 \%)$ did not have any substantial effect on the cell proliferation. Cisplatin (Ebewe Pharma GmbH, Unterach, Austria) was used as positive control.

\section{Conclusions}

Novel antiproliferative triazolyl D-secoestrone derivatives were synthesized by introducing the triazolylmethyl linker between the 3-OH and the benzyl or $p$-substituted benzyl protecting group. The "clicking" of benzyl azides to the 3-propargyl-D-secoestrones led to potent antiproliferative compounds. The synthesized derivatives differed at two sites of the molecules: in the orientation of the angular methyl function and in the nature of the substituent present on the 3-OH group. It can be stated that both variables substantially influenced the antiproliferative behavior. The 3-OH derivatives displayed the lowest growth-inhibitory action. Etherification of the phenolic $\mathrm{OH}$ group improved the cytostatic properties moderately, but the incorporation of the triazolylmethyl linker between the protecting group and the 3-O nevertheless increased the inhibitory values of the compounds substantially. 13 $\beta$-Methyl derivatives proved to be more potent than their $13 \alpha$ counterparts overall. As concerns the $p$-substituent on the $N$-benzyl ring, neither the presence of the electron-withdrawing nor that of the electron-donating group appeared to be advantageous, in contrast 
with the unsubstituted derivative. It can be concluded that the combination of the $13 \beta$-methyl and the 3-(N-benzyltriazolylmethoxy) group on the D-secoestrone scaffold intensifies the antiproliferative potential. These compounds are the most potent cell-growth-inhibitor D-secoestrones reported to date. Antiproliferative potential of $13 \alpha$-D-secoestrone derivatives is a novel finding.

Acknowledgments: The authors are grateful for financial support from the Hungarian Scientific Research Fund (OTKA K113150 and K109293). The work of Noémi Bózsity and Renáta Minorics was supported by a PhD Fellowship of the Talentum Fund of Richter Gedeon Plc. (Budapest) and a János Bolyai Research Scholarship of the Hungarian Academy of Sciences, respectively.

Author Contributions: Johanna Szabó, Nóra Jerkovics and Noémi Bózsity performed the experiments; János Wölfling and Gyula Schneider contributed reagents, materials and analysis tools; Erzsébet Mernyák, Renáta Minorics and István Zupkó conceived and designed the experiments; Erzsébet Mernyák and Renáta Minorics and István Zupkó analyzed the data; Erzsébet Mernyák and István Zupkó wrote the paper.

Conflicts of Interest: The authors declare no conflict of interest.

\section{References}

1. Newman, D.J.; Cragg, G.M. Natural products, derivatives and mimics as antitumor agents. J. Nat. Prod. 2011, 75, 311-335. [CrossRef] [PubMed]

2. Saha, S.K.; Khuda-Bukhsh, A.R. Molecular approaches towards development of purified natural products and their structurally known derivatives as efficient anti-cancer drugs: Current trends. Eur. J. Pharm. 2013, 714, 239-248. [CrossRef] [PubMed]

3. Gupta, A.; Kumar, S.B.; Negi, A.S. Current status on development of steroids as anticancer agents. J. Steroid Biochem. Mol. Biol. 2013, 137, 242-270. [CrossRef] [PubMed]

4. Numazawa, M.; Ando, M.; Watari, Y.; Tominaga, T.; Hayata, Y.; Yoshimura, A. Structure-activity relationships of 2-, 4-, or 6-substituted estrogens as aromatase inhibitors. J. Steroid Biochem. Mol. Biol. 2005, 96, 51-58. [CrossRef] [PubMed]

5. Schönecker, B.; Lange, C.; Kötteritzsch, M.; Günther, W.; Weston, J.; Anders, E.; Görls, H. Conformational design for $13 \alpha$-steroids. J. Org. Chem. 2000, 65, 5487-5497. [CrossRef] [PubMed]

6. Ayan, D.; Roy, J.; Maltais, R.; Poirier, D. Impact of estradiol structural modifications (18-methyl and/or 17-hydroxy inversion of configuration) on the in vitro and in vivo estrogenic activity. J. Steroid Biochem. Mol. Biol. 2011, 127, 324-330. [CrossRef] [PubMed]

7. Penov Gasi, K.M.; Miljkovic, D.A.; Medic Mijacevic, L.D.; Djurendic, E.A.; Stojanovic, S.Z.; Sakac, M.N.; Djurendic, M.D.; Stankovic, S.M.; Lazar, D.; Andric, S.; et al. Synthesis, X-ray crystal structure and biological activity of 16-amino-17-substituted-D-homo steroid derivatives. Steroids 2003, 68, 667-676. [CrossRef]

8. Jovanovic-Santa, S.; Petrovic, J.; Andric, S.; Kovacevic, R.; Durendic, E.; Sakac, M.; Lazar, D.; Stankovic, S. Synthesis, structure, and screening of estrogenic and antiestrogenic activity of new 3,17-substituted16,17-seco-estratriene derivatives. Bioorg. Chem. 2003, 1, 475-484. [CrossRef]

9. Nikolic, A.R.; Petri, E.T.; Klisuric, O.R.; Celic, A.S.; Jakimov, D.S.; Djurendic, E.A.; Penov Gasi, K.M.; Sakac, M.N. Synthesis and anticancer cell potential of steroidal 16,17-seco-16,17a-dinitriles: Identification of a selective inhibitor of hormone-independent breast cancer cells. Bioorg. Med. Chem. 2015, 23, 703-711. [CrossRef] [PubMed]

10. Mernyak, E.; Szabo, J.; Huber, J.; Schneider, G.; Minorics, R.; Bozsity, N.; Zupko, I.; Varga, M.; Bikadi, Z.; Hazai, E.; et al. Synthesis and antiproliferative effects of D-homo- and D-secoestrones. Steroids 2014, 87, 128-136. [CrossRef] [PubMed]

11. Mernyak, E.; Fiser, G.; Szabo, J.; Bodnar, B.; Schneider, G.; Kovacs, I.; Ocsovszki, I.; Zupko, I.; Wölfling, J. Synthesis and in vitro antiproliferative evaluation of D-secooxime derivatives of $13 \beta$ - and $13 \alpha$-estrone. Steroids 2014, 89, 47-55. [CrossRef] [PubMed]

12. Liang, L.; Astruc, D. The copper(I)-catalyzed alkyne-azide cycloaddition (CuAAC) "click" reaction and its applications. An overview. Coord. Chem. Rev. 2011, 255, 2933-2945. [CrossRef]

13. Pedersen, D.S.; Abell, A. 1,2,3-Triazoles in peptidomimetic chemistry. Eur. J. Org. Chem. 2011, 2011, 2399-2411. [CrossRef]

14. Deobald, A.M.; Camargo, L.R.S.; Alves, D.; Zukerman-Schpector, J.; Corrêa, A.G.; Paixão, M.W. Click chemistry: an efficient synthesis of heterocycles substituted with steroids, saponins, and digitalis analogues. Synthesis 2011, 24, 4003-4010. 
15. Szabo, J.; Bacsa, I.; Wölfling, J.; Schneider, G.; Zupko, I.; Varga, M.; Herman, B.E.; Kalmar, L.; Szecsi, M.; Mernyak, E. Synthesis and in vitro pharmacological evaluation of N-[(1-benzyl-1,2,3-triazol-4yl)methyl]-carboxamides on D-secoestrone scaffolds. J. Enzyme Inhib. Med. Chem. 2015. [CrossRef]

16. Kadar, Z.; Baji, A.; Zupko, I.; Bartok, T.; Wölfling, J.; Frank, E. Efficient approach to novel $1 \alpha$-triazolyl$5 \alpha$-androstane derivatives as potent antiproliferative agents. Org. Biomol. Chem. 2011, 9, 8051-8057. [CrossRef] [PubMed]

17. Kadar, Z.; Kovacs, D.; Frank, E.; Schneider, G.; Huber, J.; Zupko, I.; Bartok, T.; Wölfling, J. Synthesis and in vitro antiproliferative activity of novel androst-5-ene triazolyl and tetrazolyl derivatives. Molecules 2011, 16, 4786-4806. [CrossRef] [PubMed]

18. Frank, E.; Molnar, J.; Zupko, I.; Kadar, Z.; Wölfling, J. Synthesis of novel steroidal $17 \alpha$-triazolyl-derivatives via $\mathrm{Cu}(\mathrm{I})$-catalyzed azide-alkyne cycloaddition, and an evaluation of their cytotoxic activity in vitro. J. Steroids 2011, 76, 1141-1148. [CrossRef] [PubMed]

19. Kadar, Z.; Frank, E.; Schneider, G.; Molnar, J.; Zupko, I.; Koti, J.; Schönecker, B.; Wölfling, J. Efficient synthesis of novel A-ring-substituted 1,2,3-triazolylcholestane derivatives via catalytic azide-alkyne cycloaddition. Arkivoc 2012, 3, 279-296.

20. Kadar, Z.; Molnar, J.; Schneider, G.; Zupko, I.; Frank, E. A facile click approach to novel 15 $\beta$-triazolyl$5 \alpha$-androstane derivatives, and an evaluation of their antiproliferative activities in vitro. Bioorg. Med. Chem. 2012, 20, 1396-1402. [CrossRef] [PubMed]

21. Mernyak, E.; Kovacs, I.; Minorics, R.; Sere, P.; Czegany, D.; Sinka, I.; Wölfling, J.; Schneider, G.; Ujfaludi, Z.; Boros, I.; et al. Synthesis of trans-16-triazolyl-13 $\alpha$-methyl-17-estradiol diastereomers and the effects of structural modifications on their in vitro antiproliferative activities. J. Steroid Biochem. Mol. Biol. 2015, 150, 123-134. [CrossRef] [PubMed]

22. Jurasek, M.; Dzubak, P.; Sedlak, D.; Dvorzakova, H.; Hajduch, M.; Bartunek, P.; Drašar, P. Preparation, preliminary screening of new types of steroid conjugates and their activities on steroid receptors. Steroids 2013, 78, 356-361. [CrossRef] [PubMed]

23. Bózsity, N.; Minorics, R.; Szabó, J.; Mernyák, E.; Schneider, G.; Wölfling, J.; Wang, H.C.; Wu, C.C.; Ocsovszki, I.; Zupkó, I. Mechanism of antiproliferative action of a new D-secoestrone-triazole derivative in cervical cancer cells and its effect on cancer cell motility. J. Steroid Biochem. Mol. Biol.. under review.

24. Doorbar, J.; Quint, W.; Banks, L.; Bravo, I.G.; Stoler, M.; Broker, T.R.; Stanley, M.A. The biology and life-cycle of human papillomaviruses. Vaccine 2012, 30S, F55-F70. [CrossRef] [PubMed]

25. Pater, M.M.; Pater, A. Human papillomavirus types 16 and 18 sequences in carcinoma cell lines of the cervix. Virology 1985, 145, 313-318. [CrossRef]

26. Neve, R.M.; Chin, K.; Fridlyand, J.; Yeh, J.; Baehner, F.L.; Fevr, T.; Clark, L.; Bayani, N.; Coppe, J.P.; Tong, F.; et al. A collection of breast cancer cell lines for the study of functionally distinct cancer subtypes. Cancer Cell 2006, 10, 515-527. [CrossRef] [PubMed]

27. Huber, J.; Wölfling, J.; Schneider, G.; Ocsovszki, I.; Varga, M.; Zupkó, I.; Mernyák, E. Synthesis of antiproliferative $13 \alpha$-D-homoestrones via Lewis acid-promoted one-pot Prins-Ritter reactions of D-secosteroidal $\delta$-alkenyl-aldehydes. Steroids 2015, 102, 76-84. [CrossRef] [PubMed]

28. Pardin, C.; Roy, I.; Lubell, W.D.; Keillor, J.W. Reversible and competitive cinnamoyl triazole inhibitors of tissue transglutaminase. Chem. Biol. Drug Des. 2008, 72, 189-196. [CrossRef] [PubMed]

29. Maycock, C.D.; Santos, J.P.; Duarte, M.F.; Frenandez, M.T.; Costa, M.L. Study of selected benzyl azides by UV photoelectron spectroscopy and mass spectrometry. J. Mol. Struct. 2010, 980, 163-171.

30. Pötzsch, R.; Voit, B. Thermal and photochemical crosslinking of hyperbranched polyphenylene with organic azides. Macromol. Rapid Commun. 2012, 33, 635-639. [CrossRef] [PubMed]

31. Barr, L.; Lincoln, S.F.; Easton, C.J. A cyclodextrin molecular reactor for the regioselective synthesis of 1,5-disubstituted-1,2,3-triazoles. Supramol. Chem. 2005, 17, 547-555. [CrossRef]

32. Mosmann, T. Rapid colorimetric assay for cellular growth and survival: Application to proliferation and cytotoxicity assays. J. Immunol. Methods 1983, 65, 55-63. [CrossRef]

Sample Availability: Samples of the compounds are not available.

(C) 2016 by the authors; licensee MDPI, Basel, Switzerland. This article is an open access article distributed under the terms and conditions of the Creative Commons Attribution (CC-BY) license (http://creativecommons.org/licenses/by/4.0/). 